\title{
Small tropical islands with dense human population: Differences in water quality of near-shore waters are associated with distinct bacterial communities
}

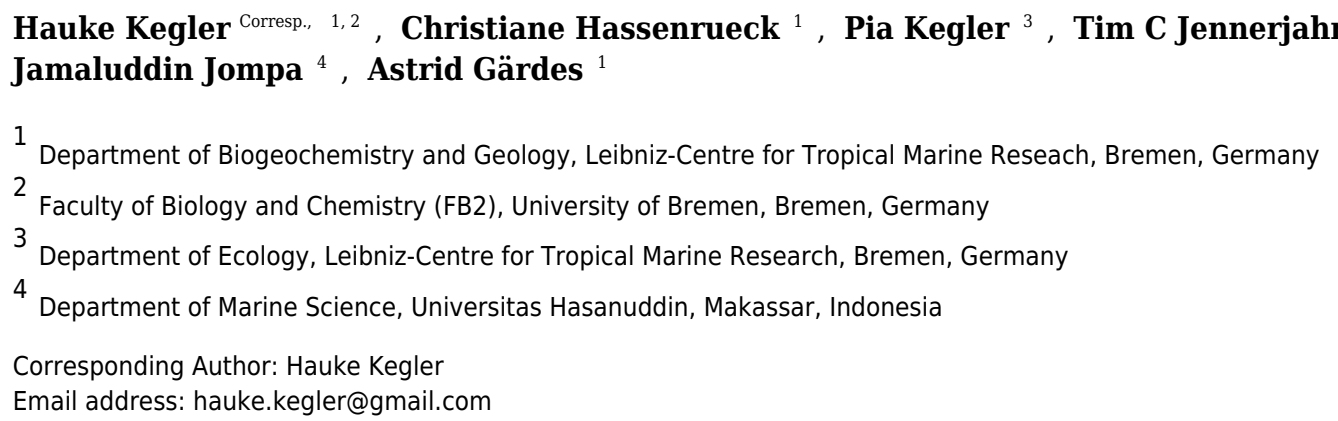

Water quality deterioration caused by an enrichment in inorganic and organic matter due to anthropogenic inputs is one of the major local threats to coral reefs in Indonesia.

However, even though bacteria are important mediators in coral reef ecosystems, little is known about the response of individual taxa and whole bacterial communities to these anthropogenic inputs. The present study is the first to investigate how bacterial community composition responds to small-scale changes in water quality in several coral reef habitats of the Spermonde Archipelago including the water column, particles and back reef sediments, on a densely populated and an uninhabited island. The main aims were to elucidate if a) water quality indicators and organic matter concentrations differ between the uninhabited and the densely populated island of the archipelago, and b) if there are differences in bacterial community composition in back-reef sediments and in the water column, which are associated with differences in water quality. Several key water quality parameters, such as inorganic nitrate and phosphate, chlorophyll a, and transparent exopolymer particles (TEP) were significantly higher at the inhabited than at the uninhabited island. Bacterial communities in sediments and particle attached communities were significantly different between the two islands with bacterial taxa commonly associated with nutrient and organic matter rich conditions occurring in higher proportions at the inhabited island. Within the individual reef habitats, variations in bacterial community composition between the islands are associated with differences in water quality. We also observed that copiotrophic, opportunistic bacterial taxa were enriched at the inhabited island with its higher chlorophyll a, dissolved organic carbon (DOC) and TEP concentrations. Given the increasing strain on tropical coastal ecosystems, this study suggests that effluents from densely populated islands lacking sewage treatment can alter 
bacterial communities that may be important for coral reef ecosystem function. 
$1 \quad$ Small tropical islands with dense human population: Differences in water quality of near-shore waters are associated with distinct bacterial communities

$8{ }^{1}$ Department of Biogeochemistry and Geology, Leibniz Centre for Tropical Marine Research, 9 Bremen, Germany

$10{ }^{2}$ Faculty of Biology and Chemistry (FB 2), University of Bremen, Bremen, Germany

$11{ }^{3}$ Department of Ecology, Leibniz Centre for Tropical Marine Research, Bremen, Germany

$12{ }^{4}$ Department of Biogeochemistry and Geology, Leibniz Centre for Tropical Marine Research,

13 Bremen, Germany

$14{ }^{5}$ Marine Science Department, Faculty of Marine Science and Fisheries, Hasanuddin University, 15 South Sulawesi, Indonesia

\section{* Correspondence}

Hauke Kegler

19 hauke.kegler@gmail.com

\section{Abstract}

Water quality deterioration caused by an enrichment in inorganic and organic matter due to anthropogenic inputs is one of the major local threats to coral reefs in Indonesia. However, even though bacteria are important mediators in coral reef ecosystems, little is known about the response of individual taxa and whole bacterial communities to these anthropogenic inputs. The present study is the first to investigate how bacterial community composition responds to small-scale changes in water quality in several coral reef habitats of the Spermonde Archipelago including the water column, particles and back reef sediments, on a densely populated and an uninhabited island. 
31 differ between the uninhabited and the densely populated island of the archipelago, and b) if there

32 are differences in bacterial community composition in back-reef sediments and in the water

33 column, which are associated with differences in water quality. Several key water quality

34 parameters, such as inorganic nitrate and phosphate, chlorophyll $a$, and transparent exopolymer

35 particles (TEP) were significantly higher at the inhabited than at the uninhabited island. Bacterial

36 communities in sediments and particle attached communities were significantly different between the two islands with bacterial taxa commonly associated with nutrient and organic matter rich conditions occurring in higher proportions at the inhabited island. Within the individual reef habitats, variations in bacterial community composition between the islands are associated with differences in water quality. We also observed that copiotrophic, opportunistic bacterial taxa were enriched at the inhabited island with its higher chlorophyll $a$, dissolved organic carbon (DOC) and TEP concentrations. Given the increasing strain on tropical coastal ecosystems, this study suggests that effluents from densely populated islands lacking sewage treatment can alter bacterial communities that may be important for coral reef ecosystem function.

\section{INTRODUCTION}

Coral reef systems in close vicinity to highly populated areas are often affected by land-based activities, e.g. intensive farming and coastal development, which can lead to additional nutrient release to near-shore waters (Bell, 1992; Gardner et al., 2003; Lapointe, 2004; Wolanski, Martinez \& Richmond, 2009; Reopanichkul et al., 2010). This increase of inorganic and organic nutrients can lead to the proliferation of macroalgae and stimulation of phytoplankton growth, with a subsequent increased light attenuation and sedimentation, effectively reducing gross photosynthesis, smothering the corals and preventing recruitment (Fabricius et al., 2003; Fabricius, 2005). Additional organic matter derived from phytoplankton production can also result in community shifts and an increased activity of the bacterial community with potentially harmful effects for corals, such as an increased prevalence of pathogens or lowered oxygen concentrations (Kuntz et al., 2005; Garren, Smriga \& Azam, 2008).

In organic matter-rich conditions, bacterial community composition can shift from autotrophic to heterotrophic in reef waters (Meyer-Reil \& Köster, 2000; Weinbauer et al., 2010; de Voogd et al., 2015), microbial biofilms (Sawall, Richter \& Ramette, 2012; Witt, Wild \& Uthicke, 2012) and 
62 sediments (Uthicke \& McGuire, 2007). This shift often occurs alongside an increase in total 63 bacterial cell counts (Zhang et al., 2007, 2009; Dinsdale et al., 2008). High bacterial abundance 64 and remineralization increase the oxygen consumption and lead to hypoxia, with potentially fatal 65 consequences for benthic organism (Kline et al., 2006). Bacteria also play an important role in 66 biogeochemical cycling and coral reef health, including nutrient cycling and anti-microbial activities (Azam et al., 1993; Azam, 1998; Rosenberg et al., 2007; Azam \& Malfatti, 2007; Stocker, 2012; Rädecker et al., 2015). Therefore, even small shifts due to anthropogenically induced eutrophication can further alter nutrient cycling activities, sedimentation and organic matter export, as well as promote coral pathogens (Bruno et al., 2003; Fabricius, 2005; Garren, Smriga \& Azam, 2008; Lyons et al., 2010).

Water quality in Indonesia has been declining in the past decade, with domestic wastewater, industry, agriculture and fish farming being the main sources of pollution (Asian Development Bank, 2016). The Spermonde Archipelago in southern Sulawesi, Indonesia, including its approximately 150 small islands, is an excellent example for such anthropogenic impacts, as several previous studies revealed (Renema \& Troelstra, 2001; Sawall, Richter \& Ramette, 2012; Plass-Johnson et al., 2015). Untreated sewage and pollutants from metropolitan Makassar (population: approx. 1.4 million) enter the system directly or via the river Jene Berang, which additionally discharges sediments, suspended particulate matter and inorganic nutrients from the hinterland (Renema \& Troelstra, 2001; Nasir et al., 2016). The Archipelago has therefore been characterized by a cross-shelf gradient from chlorophyll $a$-rich inshore to oligotrophic offshore waters (Renema \& Troelstra, 2001; Becking et al., 2006; Kegler et al., 2017). Subsequently, deteriorating coral reefs of the fringing islands in the Spermonde Archipelago could put the livelihoods of thousands of fishermen at risk (Pet-Soede et al., 2001).

In addition to anthropogenic disturbances on the larger-scale, driven by sewage and riverine input from the mainland and Makassar, many of the small islands are also densely populated and lack proper sewage and waste water treatment facilities. There is some indication that dense human populations inhabiting small islands, such as Spermonde Archipelago, can have profound effects on their physico-chemical environment (White \& Falkland, 2010). For example, on some islands there is now an imbalance between the availability and the demand of freshwater with increasing

91 human populations (Schwerdtner Máñez et al., 2012), or a pollution of the freshwater lens (White 92 \& Falkland, 2010). Therefore, groundwater seepage (Laws, Brown \& Peace, 2004; Paytan et al., 
93 2006) and freshwater runoff can be sources of inorganic and organic nutrients to the fringing reefs.

94 Those nutrients are quickly assimilated and converted into phytoplankton biomass (Koop et al.,

95 2001). Consequences are an increased release of dissolved organic carbon (DOC) and transparent

96 exopolymer particles (TEP; Karl et al., 1998; Passow, 2002) and subsequent aggregation and

97 sedimentation of large particles rich in organic matter (Kiørboe \& Hansen, 1993; Cárdenas et al., 98 2015).

There is only little information available on bacterial community composition in the Spermonde Archipelago. The studies conducted so far have focused on the diversity of settlement tile biofilms

102 (Sawall, Richter \& Ramette, 2012) and bacterial communities from different reef habitats, specifically within sponges, as well as on the functional role of the associated bacteria (Cleary et al., 2015). A more recent study investigated the abundance of potential pathogens at sites with and without seagrass meadows (Lamb et al., 2017). So far, most previous studies, except by Lamb et al. (2017), investigated changes in bacterial community composition along much larger gradients (Kegler et al., 2017). This will be the first study in the Archipelago to simultaneously investigate small-scale spatial differences in water quality and bacterial community composition while comparing two islands of different inhabitation status. It aims to elucidate (i) how the inhabitation status of two (one uninhabited and one densely populated) islands affects water quality, including

111 inorganic nutrients, chlorophyll $a$, DOC and TEP at increasing distance from the islands, and (ii)

112 how those possible differences in water quality may affect bacterial community composition

113 within the reef sediments as well as in the free-living and particle-attached fractions of the water 114 column.

\section{MATERIAL AND Methods}

\subsection{Location and characteristics of the sampling sites}

118 Two transects, each at two islands of similar distance from Makassar, (South Sulawesi, 119 Indonesia), were sampled during the dry south-east monsoon in May 2014 (Fig. 1). One island, 120 Pulau Barrang Lompo, sampled on May 19, is densely populated, with more than 4,000 people 121 inhabiting the $0.2 \mathrm{~km}^{2}$ island, while the uninhabited island Pulau Kodinggareng Keke, sampled on 122 May 29, was chosen as a reference. The two replicate transects were laid out from $25 \mathrm{~m}$ to $300 \mathrm{~m}$, 123 at depths ranging from app. $50 \mathrm{~cm}$ to a maximum of $3 \mathrm{~m}$, across the northern and southern parts 
124 of the back-reef area at each island (Fig. 1). Samples were collected at four transect points (sites)

125 at 25, 75, 150 and $300 \mathrm{~m}$ distance from the islands. All sampling was conducted while snorkeling

126 during high tide in the morning hours and completed in one day for each island. Coral reefs and

127 seagrass meadows were present in the vicinity, but care was taken not to take sediment samples

128 directly within those habitats. Temperature (average $31^{\circ} \mathrm{C}$ ), $\mathrm{pH}$ (average 8.08) and salinity

129 (average 32.8) were all within a very narrow range of less than 1\% variability across both islands.

130 The required research permits, permit no. 5599/FRP/SM/XI/2013 (Dr. Astrid Gaerdes), 131 5552/FRP/SM/XII/2013 (Dr. Hauke Kegler) and 176/SIP/FRP/SM/V/2013 (Dr. Pia Kegler) to

132 conduct fieldwork in Indonesia were provided by the Indonesian Ministry of Research,

133 Technology, and Higher Education (RISTEKDIKTI).

\subsection{Water quality parameters}

136 Chlorophyll $a$ was measured in situ, at depths ranging from app. $50 \mathrm{~cm}$ to a maximum of $3 \mathrm{~m}$, 137 with a Eureka Manta 2 multiprobe (eureka water probes, Austin, USA). Additionally, surface water 138 was collected at all sampling points in triplicates, using $5 \mathrm{~L}$ high-density polyethylene canisters, 139 washed with $1 \mathrm{M} \mathrm{HCl}$ and rinsed with distilled water, for determination of inorganic nutrients, 140 DOC and TEP. From each replicate canister subsamples of $30 \mathrm{ml}$ (DOC) and $50 \mathrm{ml}$ (inorganic 141 nutrients) each were taken. Within 3 hours of sampling, all samples were transported to the field 142 station on Pulau Barrang Lompo and kept in the dark until filtration. After filtration through a $1430.7 \mu \mathrm{m}$ pore size GF/F filter (GE Healthcare Bio-Sciences, Pittsburgh, USA), samples for inorganic 144 nutrients (nitrite, nitrate, phosphate and silicate) were immediately fixed with mercury chloride 145 and frozen at $-20^{\circ} \mathrm{C}$ until spectro-photometrical analysis with a Flowsys continuous flow analyser 146 (Systea, Anagni, Italy). To determine DOC, subsamples were filtered through a $0.45 \mu \mathrm{m}$ pore size 147 cellulose acetate syringe filter (Sartorius, Goettingen, Germany), acidified with $\mathrm{HCl}(\mathrm{pH}<2)$ and 148 frozen at $-20^{\circ} \mathrm{C}$ until further analysis. DOC concentrations were measured by high-temperature 149 oxic combustion (HTOC) using a TOC-VCPH analyzer (Shimadzu, Mandel, Canada). Hansell 150 artificial seawater standards (Hansell laboratory RSMAS, University of Miami) served as a quality 151 control, while ultrapure water was used for the blanks. For TEP analysis the spectrophotometric 152 method first introduced by Passow and Alldredge (1995) was used, with an updated protocol by 153 Engel (2009). Briefly, this method relates the adsorption of a dye to the weight of polysaccharides 154 filtered on $0.4 \mu \mathrm{m}$ pore size polycarbonate filters (GE Healthcare Bio-Sciences, Pittsburgh, USA). 
155 A calibration curve was prepared using the reference polysaccharide Gum Xanthan from

156 Xanthomonas campestris cultures.

157

158

\subsection{DNA extraction and Illumina sequencing}

159

To separate bacterioplankton into two size fractions, representing 'particle-attached' and 'freeliving' bacteria following the classification of Crump et al. (1999), a 1 L subsample from each transect point was filtered sequentially using $3 \mu \mathrm{m}$ and $0.2 \mu \mathrm{m}$ Whatman Nuclepore polycarbonate filters (GE Healthcare Bio-Sciences, Pittsburgh, USA). We applied the protocol established by Boström et al. (2004) for DNA extraction from water column samples. Surface sediment was collected from the uppermost $1 \mathrm{~cm}$ of sediment at each transect point. Sediment samples were collected in $2.0 \mathrm{~mL}$ tubes in situ (Eppendorf, Germany), stored at $-20^{\circ} \mathrm{C}$ until extraction and shipped frozen on ice. Extraction was carried out at facilities of the Leibniz Centre for Tropical Marine Research in Bremen, Germany, using the PowerSoil ${ }^{\mathrm{TM}}$ DNA Isolation Kit (MO BIO Laboratories, Carlsbad, USA) with modification of the following two steps of the protocol: 1) we did not incubate for $5 \mathrm{~min}$ at $4^{\circ} \mathrm{C}$, but centrifuged the sample directly after the addition of S2, and 2) we used $50 \mu \mathrm{L}$ of elution buffer instead of $100 \mu \mathrm{L}$. All extracted DNA samples were sequenced by LGC Genomics (Berlin, Germany) using an Illumina MiSeq V3 reagent kit (Illumina Inc., San Diego, USA). The 16S rRNA primers 341F (5'-CCTACGGGNGGCWGCAG-3') and 785R (5'-CTACCAGGGTATCTAATCC-3') were used, targeting the V3-V4 hypervariable region (Klindworth et al., 2013). For the sequencing library preparation, PCR reactions were run with approximately $5 \mathrm{ng}$ of DNA template, 15 pmol of each forward and reverse primer, and $1 \mathrm{x}$ MyTaq buffer, consisting of 1.5 units MyTaq DNA polymerase (Bioline) and $2 \mu \mathrm{L}$ of BioStabII PCR Enhancer (Sigma), in a total reaction volume of $20 \mu \mathrm{L}$. After an initial denaturation step at $96^{\circ} \mathrm{C}$ for $2 \mathrm{~min}$, PCRs were run with 30 cycles of $15 \mathrm{sec}$ at $96^{\circ} \mathrm{C}, 30 \mathrm{sec}$ at $50^{\circ} \mathrm{C}$, and $90 \mathrm{sec}$ at $70^{\circ} \mathrm{C}$.

Demultiplexed and primer-clipped sequences provided by LGC Genomics (available at the

180 European Nucleotide Archive (ENA), accession number PRJEB18570) were used for the analysis with DADA2 version 1.4 (Callahan et al., 2015) to generate operational taxonomic units (OTU) based on unique sequence variants. Briefly, sequences were quality filtered at a maximum expected error rate of 3 and a minimum length of $245 \mathrm{bp}$ and $205 \mathrm{bp}$ for forward and reverse reads, respectively. Error learning and denoising were run with default settings pooling all sequences across samples. After denoising, forward and reverse reads were merged with a minimum overlap 
186 of $10 \mathrm{bp}$ and without allowing mismatches in the overlap region. Only merged sequences with a 187 length between $380 \mathrm{bp}$ and $430 \mathrm{bp}$ were considered for further analysis. Chimera removal was 188 conducted using default settings. Then, sequences were submitted to SILVAngs (https://www.arb189 silva.de/ngs/; date accessed 02.08.2017) for taxonomic classification using the SILVA ribosomal 190 RNA gene database version 128 as reference (Quast et al., 2013). OTUs with a sequence similarity 191 of less than $93 \%$ to the reference database, OTUs unclassified on phylum level, and OTUs 192 affiliated with eukaryotic, archaeal, mitochondrial, or chloroplast sequences were removed from 193 the data set. $\mathrm{R}$ and bash scripts for sequence processing are available as supplementary material. 194 DADA2 was run in R version 3.4.1 (R Core Team, 2016).

195

196

\subsection{Statistical analysis}

A principle component analysis (PCA) was conducted to visualize changes in water quality parameters among samples.

Differences in individual water quality parameters between islands and with increasing distance from the island were assessed using general linear mixed models (GLMM) with transect as random factor (Kuznetsova, Brockhoff \& Christensen, 2016). Prior to analysis, values were logtransformed to meet the assumption of normality.

203

Alpha diversity of the bacterial communities was assessed based on the Inverse Simpson Index 205 (Hill, 1973) after randomly rarefying the data set repeatedly to the minimum library size (964 sequences). Differences in alpha diversity between islands and correlations with water quality parameters were assessed using non-parametric Wilcoxon tests and Spearman correlations, 208 respectively.

Non-metric multidimensional scaling (NMDS), based on Bray-Curtis dissimilarities of relative sequence abundances, was conducted to visualize patterns in the bacterial community composition

211 for each habitat. Correlations of patterns in community composition and water quality parameters 212 were mapped onto the NMDS plot using the R function envfit of the vegan package (Oksanen et 213 al., 2016). Analysis of similarity (ANOSIM) was used to assess the separation of bacterial 214 communities between different habitats, and between the two islands within the same habitat based 215 on Bray-Curtis dissimilarity coefficients (Clarke, 1993). 
216 Redundancy analyses (RDA; (Legendre \& Legendre, 1998) were run to evaluate the ability of 217 the inhabitation status of the islands (inhabited, uninhabited) to explain the variation in bacterial 218 community composition. Prior to RDA, OTUs that only occurred once at either of the islands were 219 removed from the data set. Furthermore, sequence counts were centered log ratio (clr)-transformed 220 using the R function aldex.clr of the ALDEx2 package (Fernandes et al., 2014) using median 221 values of 128 Monte-Carlo instances. To compare the explanatory power of inhabitation status and 222 water quality parameters, additional RDA models were constructed with water quality parameters 223 as predictors. Separate models were run with either inhabitation status or water quality parameters 224 as predictors. Forward model selection was used after checking for variance inflation to determine 225 the water quality parameters to be included in the RDA models. In cases where more than one 226 water quality parameter was selected, pure effects were also tested accounting for the variation explained by the other factors in the model.

228 Variance inflation factors (VIFs) of the individual water quality parameters were used to check 229 for collinearity among predictors. None of the parameters in any of the RDA models displayed 230 VIFs larger than 10. The water quality parameters best suited for the model were further 231 determined using forward model selection based on the minimum Akaike information criterion. 232 The adjusted $\mathrm{R}^{2}$ is provided as goodness-fit-statistic.

233

234 Random forest analysis (Liaw \& Wiener, 2002) was conducted to identify the OTUs that are 235 most important for differentiating bacterial communities from the inhabited and the uninhabited island. As importance criterion mean decrease in accuracy of the random forest models was selected. For each habitat, 10001 random trees were generated. Model significance and accuracy were assessed using permutation tests and leave-one-out cross-validation, respectively, following the tutorial provided on https://github.com/LangilleLab/microbiome_helper/wiki/Random-ForestTutorial (date accessed 09.08.2017).

For the statistical analysis we used the following $\mathrm{R}$ version and software packages: R software, version 3.3.2 (R Core Team, 2016) and R-Studio, version 1.0.153 (RStudio Team, 2017), 'vegan'

243 (Oksanen et al., 2016) for PCA and RDA, 'ImerTest' (Kuznetsova, Brockhoff \& Christensen, 244 2016) for the GLMM, 'mada' (Doebler \& Holling, 2015) for the calculation of confidence intervals of Spearman correlation coefficients, 'iNEXT' (Hsieh, Ma \& Chao, 2016) for the rarefaction analysis as well as 'caret' (Kuhn, 2017), 'rfUtilities' (Jeffrey \& Murphy, 2017) and 'randomForest' 
247 (Liaw \& Wiener, 2002) for the random forest analysis. Additional packages used within R were 248 'ALDEx2' (Fernandes et al., 2014), 'ape' (Paradis, Claude \& Strimmer, 2004), 'car' (Fox, Friendly 249 \& Weisberg, 2013), , 'gplots' (Warnes et al., 2016), , , , 'permute' (Simpson, 2016), 'plyr' 250 (Wickham, 2011), and 'reshape' (Wickham, 2007). Throughout the manuscript concentrations of 251 water quality parameters are given as arithmetic mean \pm standard deviation. The R scripts for the 252 statistical data analysis as well as figure generation are available as supplementary material.

253

2543 RESULTS

2553.1 Water quality parameters

256 Based on GLMMs, all measured water quality parameters, except silicate, were significantly 257 higher at the inhabited than at the uninhabited island. Additionally, we observed a decrease from 258

259 the sampling point closest to the island to the reef crest that was also statistically significant for all parameters, except silicate and DOC (Fig. 2, Tab. 1, Tab. S1). However, in case of DOC as well as PO4 and chlorophyll $a$, we further detected a significant interaction between island and distance from island, indicating that the trend with increasing distance was different between the two islands (Tab. 1). The highest $\mathrm{NO}_{\mathrm{x}}{ }^{-}$(Fig. 2A) and inorganic phosphate (Fig. 2B) concentrations $(0.59 \pm 0.01$ $\mu \mathrm{mol} \mathrm{L}-1$ and $0.18 \pm 0.01 \mu \mathrm{mol} \mathrm{L}^{-1}$, respectively) were measured on the southern transect of the inhabited island, compared to highest concentrations of $0.16 \pm 0.01$ and $0.14 \pm 0.01 \mu \mathrm{mol} \mathrm{L}^{-1}$, respectively, at the uninhabited island. At both transects, north and south, chlorophyll $a$ concentrations were higher at the inhabited than at the uninhabited island (Fig. 2D). Concentrations of the two different classes of organic matter, DOC (Fig. 2E) and TEP (Fig. 2F), were also higher at the inhabited island. The lowest DOC concentrations $\left(67.40 \pm 1.00 \mu \mathrm{mol} \mathrm{L}^{-1}\right)$ were measured on the southern transect of the uninhabited island, while the highest concentration (95.76 \pm 9.06 $\mu \mathrm{mol} \mathrm{L}-1)$ was measured at the southern transect of the inhabited island. TEP concentrations at the inhabited island were approximately three times higher $(184.36 \pm 42.59$ compared to $67.78 \pm 6.59$ $\mu \mathrm{g}$ Xeq $\times \mathrm{L}^{-1}$ at the uninhabited island). The first two principal components of the PCA (Fig. 3, 273 Tab. S2) accounted for $70.8 \%$ of the variation in water quality parameters among islands. The sampling sites from the inhabited island separated from those of the uninhabited one by the first principal component. Those differences along the first main principal component were mainly driven by TEP, $\mathrm{PO}_{4}{ }^{3-}, \mathrm{NO}_{\mathrm{x}}{ }^{-}$and DOC (Tab. S2). Differences along the second principal component 
277 were driven by chlorophyll $a$ and silicate, separating the northern transect of the inhabited from

278 the southern transect of the uninhabited island.

279

280

\subsection{Bacterial diversity and community composition}

281

In total, we obtained 488,370 quality-checked sequences with an average 11,099 sequences per

282 sample (ranging from 964 to 49,329 reads), corresponding to 3834 denoised unique sequence 283 variants (OTUs). After rarefaction, the number of OTUs per sample ranged from 125 to 600 . Highest average OTU counts (532) were obtained from the sediments, compared to 219 and 180 from the particle-attached and free-living fraction of the water column, respectively. Average inverse Simpson indices were also highest in samples obtained from the sediment, followed by the free-living and particle-attached fraction of the water column (Fig. S1, Fig. S2, Tab. S3).

Most of the sequences obtained from the sediment bacterial communities were affiliated with

Gamma- and Alphaproteobacteria, as well as Flavobacteriia, Planctomycetacia and Deltaproteobacteria (Fig. 4). Among the latter two bacterial classes, Planctomycetacia were predominantly found at the uninhabited island constituting on average $17 \%$ of the sequences as opposed to $8 \%$ at the inhabited island, whereas Deltaproteobacteria comprised about $10 \%$ at the inhabited island compared to $6 \%$ at the uninhabited island. Water column bacterial communities, both free-living and particle-attached, also consisted mostly of Gammaproteobacteria, Alphaproteobacteria, and Flavobacteriia (Fig. 4). In the particle-attached fraction, Cyanobacteria further constituted a large proportion of sequences of on average $43 \%$ at the uninhabited and $37 \%$ at the inhabited island. Among these dominant bacterial classes, two and eight times higher proportions of Alphaproteobacteria and Flavobacteriia, respectively, were detected at the inhabited island in the free-living fraction. A similar trend was observed in particle-attached communities, although far less pronounced (Fig. 4).

301

At OTU-level resolution, distinct bacterial communities were observed within each of the different sampled habitats (ANOSIM, $\mathrm{R}=0.91, p=0.001$; Fig. S3), with the strongest separation between sediment and water column communities. NMDS plots based on Bray-Curtis

304 dissimilarities of bacterial communities from each of the sampled habitats further showed that samples from the inhabited and uninhabited island tended to cluster apart from each other (Fig. 5). These differences in community composition between the inhabited and uninhabited island were 307 highest for sediment bacterial communities (ANOSIM, $\mathrm{R}=0.67, p=0.001$ ), with average Bray- 
308 Curtis-dissimilarities of $55-60 \%$ at each island and $70 \%$ between the two islands. Within the free-

309 living and particle-attached fraction, bacterial communities from the inhabited and uninhabited

310 island were not well separated, and this separation was only found to be significant for the particle-

311 attached communities due to the lower sample size for free-living communities at the uninhabited

312 island (Free-living: ANOSIM, $\mathrm{R}=0.25, p=0.087$; Particle-attached: ANOSIM, $\mathrm{R}=0.26, p=$

313 0.002). Average Bray-Curtis-dissimilarities were higher at the inhabited island for both free-living

314 (64\% compared to 55\%) and particle-attached (64\% compared to 44\%) bacterial communities (Fig.

$315 \mathrm{~S} 3 \mathrm{~A})$. Apart from the inhabitation status of the islands, patterns in bacterial community

316 composition, as depicted in the NMDS plots, appeared to be strongly correlated with observed

317 water quality parameters, predominantly chlorophyll $a$, inorganic phosphate and TEP (Fig. 5).

318 RDA confirmed that the inhabitation status of the islands had highest explanatory power for 319 sediment bacterial communities (RDA, $\mathrm{R}^{2}=0.18, \mathrm{~F}_{1,14}=4.382, \mathrm{p}<0.001$; Tab. 2$)$. The amount of

320 variation in bacterial community composition explained by inhabitation status for the free-living 321 and particle-attached fraction was considerably lower, although still statistically significant (RDA, $322 \mathrm{R}^{2}=0.10, \mathrm{~F}_{1,10}=2.230, \mathrm{p}=0.011$ and $\mathrm{R}^{2}=0.10, \mathrm{~F}_{1,14}=2.619, \mathrm{p}=0.001$, respectively; Tab. 2).

323 The measured water quality parameters were often equally or better suited to explain community 324 variability within the habitats (Tab. 2). Chlorophyll $a$ combined with inorganic phosphate 325 accounted for almost $30 \%$ of the variability in free-living communities, with each parameter 326 individually contributing about $17 \%$, and slightly improving the model fit compared to using 327 inhabitation status as predictor (Tab. 2). For the particle-attached fraction, chlorophyll $a$ in 328 combination with TEP explained approximately $15 \%$ of the variability in community composition, 329 whereas for sediment communities, chlorophyll $a$ was as good a predictor as inhabitation status $330 \quad\left(\mathrm{RDA}, \mathrm{R}^{2}=0.16, \mathrm{~F}_{1,14}=3.979, \mathrm{p}<0.001\right.$; Tab. 2).

We applied random forest models to the bacterial communities within the individual habitats to 332 identify which OTUs were best suited to distinguish the inhabitation status of the islands. In 333 general, the random forest models performed very well with an estimated out-of-bag error of less 334 than 0.1, corresponding to one misclassified sample (Tab. S4). OTUs most important for the 335 classification of inhabitation status were selected at a mean decrease in accuracy of more than $3360.0020,0.0030$, and 0.0016 for free-living, particle-attached, and sediment communities, 337 respectively (Tab. S4). Within the free-living fraction, especially OTUs of the NS5 marine group 338 of the Flavobacteriia were enriched at the inhabited island, as well as the gammaproteobacterial 
339 genus Litoricola and the alphaproteobacterial PS1 clade (Fig. S4). Among the depleted groups at

340 the inhabited island were mainly taxa from the class Gammaproteobacteria, although from

341 different genera as those showing enrichment, namely Alcanivorax, Pseudoalteromonas and the

342 ZD0417 marine group. In the particle-attached fraction mainly taxa from the classes

343 Gammaproteobacteria (e.g. Alteromonadaceae, Marinobacterium and Litoricola) and

344 Flavobacteriia (Flavobacteriaceae and Cryomorphaceae) were enriched at the inhabited island

345 (Fig. S4). Only one genus of the Flavobacteriia, Algitalea, was depleted in the particle-attached

346 size fraction at the inhabited island. There were no taxa exhibiting a comparably strong enrichment

347 or depletion in the sediment communities, since those communities displayed a more even OTU

348 distribution. Nevertheless, pronounced differences in predominantly OTUs of the genera

349 Bythopirellula, Rhodopirellula and Blastopirellula (Planctomycetacia), which were depleted at

350 the inhabited island, were observed. In contrast, Desulfobulbaceae and other deltaproteobacterial

351 taxa, as well as Robiginitalea and Actibacter of the Flavobacteriia, were enriched at the inhabited

352 island. This resulted in a well-supported classification of inhabitation status in the random forest

353 model (Fig. S4). These OTUs with the highest importance in the random forest models contributed

354 substantially to the bacterial communities in each habitat at the inhabited island, in some samples

355 comprising more than $40 \%, 60 \%$, and $8 \%$ each of the sequences in the free-living, particle-attached

356 and sediment communities, respectively.

357

3584 DiscuSSION

3594.1 Inhabitation status determines water quality

360 Our results indicate that coastal waters around the inhabited island are significantly affected by 361 anthropogenic inorganic and organic nutrient input. In the absence of other nutrient sources, e.g. 362 rivers or surface runoff, a likely source of inorganic nutrient input is untreated sewage outflow that 363 enters the reef waters through diffusive groundwater seepage (D'Elia, Webb \& Porter, 1981; 364 Hwang, Lee \& Kim, 2005). This can lead to elevated concentrations of inorganic nutrients and 365 DOC in the near-shore areas compared to sampling sites further out on the shelf, as was observed 366 in this study as well as at other, larger islands (Umezawa et al., 2002; Kim, 2003; Street et al., 367 2008). Those observations of declining concentrations (with the exception of chlorophyll $a$ ) from 368 sampling sites very close to the island to the ones further out on the reef flat, resemble patterns and 369 concentrations also observed at several other tropical and subtropical reef locations in the 
370 Hawaiian Archipelago, USA (Laws, Brown \& Peace, 2004) and in Moorea, French Polynesia

371 (Nelson et al., 2011). Declining concentrations of organic and inorganic nutrients are often related

372 to biological and physical removal processes including dilution within the back-reef. Biological

373 removal processes usually consist of the rapid assimilation of inorganic nutrients by benthic

374 macroalgae (Koop et al., 2001; Lapointe, Barile \& Matzie, 2004) and phytoplankton (Hallock \&

375 Schlager, 1986). Dissolved organic matter (DOM) released by phytoplankton, if not taken up by

376 bacteria, often aggregates into larger molecules, such as TEP and ultimately particulate organic

377 matter (POM; Passow and Alldredge, 1994; Verdugo et al., 2004) and subsequently settles to the

378 sediment, where it is metabolized by heterotrophic bacteria (Wild et al., 2004). Therefore, in

379 addition to physically smothering benthic organisms by the amount of settling particles rich in

380 organic matter (Fabricius et al., 2003; Golbuu et al., 2008) it can also harm them via a decreased

381 oxygen availability (Kline et al., 2006) and a shallowing of the oxic sediment layers (Brocke et al.,

382 2015).

383 In this study, apart from dilution, a large proportion of the introduced inorganic and organic 384 nutrients is likely assimilated, e.g. by phytoplankton, benthic algae or seagrass, and transformed 385 into the particulate fraction or metabolized close to the inhabited island, as measured 386 concentrations decreased across the back-reef gradients. Such a rapid depletion across back-reef 387 areas has been previously described for DOC, in that case by bacteria (Nelson et al., 2011).

388 Furthermore, an immediate uptake of available inorganic nutrients by phytoplankton likely led to

389 the observed differences in chlorophyll $a$ concentrations, which were much more prominent than

390 the differences in inorganic nutrient availability between the uninhabited and inhabited island

391 (Furnas et al., 2005). The quantification of inorganic and organic nutrients may therefore not

392 always be the most suitable indicator for anthropogenic eutrophication, unless they are combined

393 with measurements of biological indicators, such as chlorophyll $a$ concentrations or microbial

394 community composition (Paerl et al., 2003b,a). It is also noteworthy that during high tide 395 concentrations of chlorophyll $a$ and inorganic nutrients are often lower than during low tide 396 (Welch \& Isaac, 1967; Szmant \& Forrester, 1996). Thus, the concentrations reported in this study 397 are likely underestimating the terrestrial input compared to low tide measurements. 398

\subsection{Bacterial community composition: differences between habitats and islands}


400

401

402

403

404

405

406

407

408

409

410

411

412

413

414

415

416

417

418

419

420

421

422

423

424

425

426

427

428

429

430

Taking all samples into account, habitat was the main factor determining community composition. This is supported by many studies from tropical coral reef ecosystems, including the Spermonde Archipelago, which showed distinct bacterial communities between various habitats within the reefs (Rohwer et al., 2002; Tout et al., 2014; Polónia et al., 2015; Cleary et al., 2015; Kegler et al., 2017). Different habitats vary considerably in substrate heterogeneity, colonizable surfaces and food availability (Bourne \& Webster, 2013), and will favor different bacterial life strategies (Lauro et al., 2009). Thus, investigations trying to disentangle the driving forces of community variability along gradients of water quality parameters should focus on the withinhabitat differences of bacterial community composition. Indeed, while we detected differences in bacterial community composition correlated to changes in water-quality parameters in all investigated habitats, the response of different OTUs varied in each habitat. Therefore, we suggest separating not only sediment and water column bacterial communities, but also distinguishing freeliving and particle-attached fractions within the water column in the analysis, especially in anthropogenically influenced coastal settings.

Interestingly, we observed opposite trends in the explanatory power of water quality parameters and inhabitation status from free-living to particle-attached to sediment bacterial communities. While inhabitation status on its own was not well suited to explain patterns in community composition within the free-living fraction, water quality parameters correlated strongly. Conversely, differences in sediment bacterial communities were best described by inhabitation status or chlorophyll $a$ concentration, the water quality parameter with the most pronounced differences between the inhabited and uninhabited island. These observed differences in bacterial community response to changes in water quality may be subsequently attributed to individual taxon responses.

In this study, several OTUs from the Flavobacteriia were enriched in the free-living and particle-attached fractions of the water column at the inhabited island compared to the same habitats at the uninhabited island. Within the free-living fraction of the water column the NS5 marine group of Flavobacteriia were previously described to significantly correlate with phytoplankton blooms of Akashiwo sanguine followed by high abundances of Litoricola (Yang et al., 2015), which was also detected here in higher proportions at the inhabited island. Flavobacteriia, the largest class within the phylum Bacteroidetes, are key players in the initial degradation of the high molecular mass fraction of organic matter derived from algae production 
431 and detritus (Kirchman, 2002; Pinhassi et al., 2004). In the back-reef area of the inhabited island, 432 chlorophyll $a$ as proxy for phytoplankton abundance was consistently higher than at the 433 uninhabited island. This may explain the higher proportion of Flavobacteriia, and within that class 434 the observed NS5 marine group, and is consistent with observations of other studies (Pinhassi et 435 al., 2004; Williams et al., 2013). After the initial degradation of the high molecular mass DOM, 436 more labile DOM is available for bacterial groups specialized in the uptake in lower molecular 437 weight polysaccharides and other more labile phytoplankton exudates, such as SAR11 and 438 Rhodobacterales (both Alphaproteobacteria) and Gammaproteobacteria (Morris, Frazar \& 439 Carlson, 2012; Williams et al., 2013), of which especially the latter were often enriched at 440 sampling stations high in nutrients or organic matter. Thus, they can be considered the start of the 441 chain of DOM degradation fueling the microbial loop (Azam et al., 1983; Fenchel, 2008).

442 Particle-associated bacterial communities were further mainly enriched in OTUs belonging to 443 the family Alteromonadaceae and the genus Marinobacterium, both members of the class 444 Gammaproteobacteria. They feature a diverse repertoire of extracellular, hydrolytic enzymes, 445 which enable them to access and assimilate various forms of organic matter on the aggregates in 446 the water column or in the sediments (Azam \& Malfatti, 2007; Edwards et al., 2010). Therefore, 447 the observed higher diversity at the inhabited compared to the uninhabited island may be explained 448 by OTUs from taxa being well adapted to using various forms of organic matter. 449 Gammaproteobacteria is also a class which contains many strains of potentially pathogenic 450 bacteria, such as Vibrio spp., and aggregates are known to be a hot-spot for pathogens (Dinsdale 451 et al., 2008; Garren et al., 2009; Lyons et al., 2010). Particles with a higher abundance of 452 potentially pathogenic bacteria can act as vectors for diseases from the water column to the 453 sediments or via ingestion to higher trophic levels (Lyons et al., 2005). Pathogens already 454 identified and found to be significantly enriched on aggregates in shallow coastal areas include the 455 genera Vibrio and Mycobacteria, as well as the fecal indicator bacterium Escherichia coli (Lyons 456 et al., 2007, 2010). Here, we observed a comparable pattern, detecting potentially pathogenic taxa, 457 especially the genus Vibrio, in similar proportions at both the inhabited and the uninhabited island, 458 although their total sequence contribution did not exceed 4\% (Fig. S5). Notably, no correlation of 459 the proportion of potentially pathogenic taxa with water quality has been previously reported for 460 the Spermonde Archipelago on a large scale, although the prevalence of potential pathogens was 461 generally high (Kegler et al., 2017). Therefore, although we cannot confirm the pathogenicity of 
462 individual OTUs in this study, and Gammaproteobacteria and Vibrio sp. are also naturally 463 occurring in healthy ecosystems, close monitoring and further identification may help to avoid 464 disease outbreaks.

465 Among the taxa enriched in the sediment samples at the anthropogenically impacted island, 466 were, apart from the previously mentioned Flavobacteriia and Gammaproteobacteria, OTUs of 467 the family Desulfobulbaceae. In organic matter-rich sediments, oxygen is quickly consumed in the 468 upper, well-aerated layer of the sediment, and replaced by sulfate as electron acceptor in the 469 degradation of organic matter, thereby leading to the expansion of hydrogen sulfide-rich layers, 470 which are toxic to oxygen-consuming organisms (Nielsen et al., 2010). Desulfobulbaceae, also 471 referred to as cable bacteria, are capable of preventing this expansion through a coupling of sulfide 472 oxidation in anoxic sediment layers to oxygen reduction in oxic layers, spanning up to $1.5 \mathrm{~cm}$ 473 (Pfeffer et al., 2012; Reguera, 2012). There, Desulfobulbaceae can prevent the expansion of 474 sediment layers enriched in hydrogen sulfide and thus mitigate the effects of high organic matter 475 loading. Although we did not measure hydrogen sulfide concentration or the oxygen penetration 476 depth of the sediment, the occurrence of these bacteria, together with other potentially sulfate477 reducing taxa also found in this study (Fig. S3, e.g. Desulfosarcina, Desulfofustis or 478 Desulfococcus), may indicate an increased availability of hydrogen sulfide in the deeper sediment 479 layers at the inhabited island. In general, the occurrence of sulfate-reducing bacteria in reef 480 sediments is common in the Indo-Pacific (Hassenrück et al., 2016; Cleary et al., 2017). Additionally, predictions are that with increasing urbanization of coastal areas, an increased release of nutrients and subsequent settlement of particles rich in organic matter, anaerobic sulfatereducing bacteria will benefit from shallower oxic layers (Brocke et al., 2015). This could also affect coral health, as sulfate-reducing bacteria are an integral part of the microbial consortium responsible for black band disease in scleractinian corals (Carlton \& Richardson, 1995; Bourne, Muirhead \& Sato, 2011; Sato et al., 2017).

Overall, multiple lines of evidence suggest that small-scale changes in water quality between the inhabited and uninhabited island had strong effects on overall bacterial community composition. Especially TEP, phosphate, and chlorophyll $a$ were highly correlated with differences in bacterial community composition between the inhabited and uninhabited island. Such island or reef-scale impacts of anthropogenic inorganic nutrient input are a novel finding for the Spermonde Archipelago, as local drivers of bacterial community variability were neglected in 
493 previous investigations. With that regard it might be an ideal model region to study the effects of 494 even minute nutrient enrichments caused by local island populations on bacterial community 495 composition. As almost all the islands are densely populated, equipping a few with basic sewage 496 treatment facilities, e.g. septic tanks, could help to elucidate whether nutrient loadings and bacterial 497 community composition around those 'model islands' would resemble those of uninhabited islands 498 of the region. This is of high relevance to regional management initiatives, especially since even 499 such small changes often favor opportunistic, copiotrophic and potentially pathogenic bacteria 500 (Eilers, Pernthaler \& Amann, 2000; Dinsdale et al., 2008). In that regard, future studies should 501 additionally include a functional analysis of the activity of observed bacterial communities, such 502 as RNA sequencing, to detect pathogenicity or their functional role in organic matter degradation 503 in identified bacterial taxa.

\subsection{Conclusion}

Overall, based on the differences between the uninhabited and the densely populated island, we infer that small island populations with limited wastewater treatment facilities can affect water quality in the surrounding back-reef area, which, in turn, shapes distinct bacterial communities. Most of the measured parameters were significantly elevated close to the inhabited island compared to samples from off the reef crest and the uninhabited island. This local eutrophication seems to be very limited compared to large-scale impacts of riverine and sewage input from the main land, e.g. in near-shore zones and estuaries (Udy et al., 2005; Zhang et al., 2007;

513 Reopanichkul et al., 2010). However, even the relatively small inputs of inorganic and organic

514 nutrients shape a bacterial community that is dominated by classes Flavobacteriia and 515 Gammaproteobacteria, which contain many opportunistic, copiotrophic bacterial taxa specialized 516 in the degradation of organic matter. These shifts in bacterial community composition, in turn, 517 could therefore also imply negative consequences for human or reef organism health. From a 518 management perspective it appears (i) that those quickly responding bacterial communities may 519 serve as priority bioindicators, and (ii) that sewage treatment is urgently required for these small 520 islands.

\section{ACKNOWLEDGEMENTS}


524 We would like to sincerely thank our Indonesian partners at Universitas Hasanuddin and the staff

525 of the Barrang Lompo field station, and especially Nur Abu and Pak Ridwan, for technical support

526 during the field work. We are further indebted to the Ministry of Research, Technology and Higher

527 Education of the Republic of Indonesia (RISTEKDIKTI) for issuing the necessary permits. Our

528 gratitude further goes to the technicians at the Leibniz Centre for Tropical Marine Research,

529 Bremen, especially Matthias Birkicht and Dorothee Dasbach, for invaluable assistance with

530 laboratory analyses.

531

\section{REFERENCES}

533

534

535

536

537

538

539

540

541

542

543

544

545

546

547

548

549

550

551

552

553

554

555

556

557

558

559

560

561

562

563

564

Asian Development Bank. 2016. Indonesia: Country Water Assessment. Mandaluyong City, Philippines: Asian Development Bank.

Azam F. 1998. Microbial Control of Oceanic Carbon Flux: The Plot Thickens. Science 280:694696. DOI: 10.1126/science.280.5364.694.

Azam F., Fenchel T., Field J., Gray J., Meyer-Reil L., Thingstad F. 1983. The Ecological Role of Water-Column Microbes in the Sea. Marine Ecology Progress Series 10:257-263. DOI: $10.3354 /$ meps010257.

Azam F., Malfatti F. 2007. Microbial structuring of marine ecosystems. Nature reviews. Microbiology 5:782-791. DOI: 10.1038/nrmicro1747.

Azam F., Smith DC., Steward GF., Hagström Å. 1993. Bacteria-Organic Matter Coupling and Its Significance for Oceanic Carbon Cycling. Microbial Ecology 28:167-179. DOI: 10.1007/s00248-004-0058-y.

Becking LE., Cleary DFR., Voogd NJ., Renema W., Beer M., Soest RWM., Hoeksema BW. 2006. Beta diversity of tropical marine benthic assemblages in the Spermonde Archipelago, Indonesia. Marine Ecology 27:76-88. DOI: 10.1111/j.1439-0485.2005.00051.x.

Bell PRF. 1992. Eutrophication and coral reefs-some examples in the Great Barrier Reef lagoon. Water Research 26:553-568. DOI: 10.1016/0043-1354(92)90228-V.

Boström K., Simu K., Hagström Å., Riemann L. 2004. Optimization of DNA extraction for quantitative marine bacterioplankton community analysis. Limnology and Oceanography: Methods:365-373. DOI: http://dx.doi.org/10.4319/lom.2004.2.365.

Bourne DG., Muirhead A., Sato Y. 2011. Changes in sulfate-reducing bacterial populations during the onset of black band disease. ISME Journal 5:559-564. DOI: 10.1038/ismej.2010.143.

Bourne DG., Webster NS. 2013. Coral Reef Bacterial Communities. In: Rosenberg E, DeLong EF, Lory S, Stackebrandt E, Thompson F eds. The Prokaryotes - Prokaryotic Communities and Ecophysiology. Berlin, Heidelberg: Springer Berlin Heidelberg, 163-187. DOI: 10.1007/9783-642-30123-0.

Brocke HJ., Polerecky L., De Beer D., Weber M., Claudet J., Nugues MM. 2015. Organic matter degradation drives benthic cyanobacterial mat abundance on caribbean coral reefs. PLoS ONE 10:1-19. DOI: 10.1371/journal.pone.0125445.

Bruno JF., Petes LE., Drew Harvell C., Hettinger A. 2003. Nutrient enrichment can increase the severity of coral diseases. Ecology Letters 6:1056-1061. DOI: 10.1046/j.14610248.2003.00544.x. 
565 Callahan BJ., Mcmurdie PJ., Rosen MJ., Han AW., Johnson AJ., Holmes SP. 2015. DADA2 : 566 High resolution sample inference from amplicon data. bioRxiv:0-14. DOI: 10.1101/024034.

567

568

569

570

571

572

573

574

575

576

577

578

579

580

581

582

583

584

585

586

587

588

589

590

591

592

593

594

595

596

597

598

599

600

601

602

603

604

605

606

607

608

609

610
Cárdenas A., Meyer F., Schwieder H., Wild C., Gärdes A. 2015. The formation of aggregates in coral reef waters under elevated concentrations of dissolved inorganic and organic carbon: A mesocosm approach. Marine Chemistry 175:47-55. DOI: 10.1016/j.marchem.2015.04.002.

Carlton RG., Richardson LL. 1995. Oxygen and sulfide dynamics in a horizontally migrating cyanobacterial mat: Black band disease of corals. FEMS Microbiology Ecology 18:155-162. DOI: 10.1016/0168-6496(95)00052-C.

Clarke KR. 1993. Non-parametric multivariate analyses of changes in community structure. Australian Journal of Ecology 18:117-143. DOI: 10.1111/j.1442-9993.1993.tb00438.x.

Cleary DFR., Polónia ARM., Becking LE., de Voogd NJ., Purwanto., Gomes H., Gomes NCM. 2017. Compositional analysis of bacterial communities in seawater, sediment, and sponges in the Misool coral reef system, Indonesia. Marine Biodiversity:1-13. DOI: 10.1007/s12526017-0697-0.

Cleary DFR., de Voogd NJ., Polónia ARM., Freitas R., Gomes NCM. 2015. Composition and Predictive Functional Analysis of Bacterial Communities in Seawater, Sediment and Sponges in the Spermonde Archipelago, Indonesia. Microbial Ecology 70:889-903. DOI: 10.1007/s00248-015-0632-5.

Crump BC., Armbrust E V., Baross J a. 1999. Phylogenetic analysis of particle-attached and freeliving bacterial communities in the Columbia river, its estuary, and the adjacent coastal ocean. Applied and environmental microbiology 65:3192-204.

D’Elia CF., Webb KL., Porter JW. 1981. Nitrate-rich groundwater inputs to Discovery Bay, Jamaica: A significant source of N to local coral reefs? Bulletin of Marine Science 31:903910.

Dinsdale EA., Pantos O., Smriga S., Edwards RA., Angly F., Wegley L., Hatay M., Hall D., Brown E., Haynes M., Krause L., Sala E., Sandin SA., Thurber RV., Willis BL., Azam F., Knowlton N., Rohwer F. 2008. Microbial ecology of four coral atolls in the Northern Line Islands. PloS ONE 3:e1584. DOI: 10.1371/journal.pone.0001584.

Doebler P., Holling H. 2015. Meta-Analysis of Diagnostic Accuracy with mada. $R$ packages:115.

Edwards JL., Smith DL., Connolly J., McDonald JE., Cox MJ., Joint I., Edwards C., McCarthy AJ. 2010. Identification of carbohydrate metabolism genes in the metagenome of a marine biofilm community shown to be dominated by Gammaproteobacteria and Bacteroidetes. Genes 1:371-384. DOI: 10.3390/genes1030371.

Eilers H., Pernthaler J., Amann R. 2000. Succession of Pelagic Marine Bacteria during Enrichment: a Close Look at Cultivation-Induced Shifts. Applied and Environmental Microbiology 66:4634-4640. DOI: 10.1128/AEM.66.11.4634-4640.2000.

Engel A. 2009. Determination of Marine Gel Particles. In: Wurl O ed. Practical Guidelines for the Analysis of Seawater. Boca Raton: CRC Press, 125-140.

Fabricius KE. 2005. Effects of terrestrial runoff on the ecology of corals and coral reefs: review and synthesis. Marine Pollution Bulletin 50:125-146. DOI: 10.1016/j.marpolbul.2004.11.028.

Fabricius K., Wild C., Wolanski E., Abele D. 2003. Effects of transparent exopolymer particles and muddy terrigenous sediments on the survival of hard coral recruits. Estuarine, Coastal and Shelf Science 57:613-621. DOI: 10.1016/S0272-7714(02)00400-6.

Fenchel T. 2008. The microbial loop - 25 years later. Journal of Experimental Marine Biology 
611

612

613

614

615

616

617

618

619

620

621

622

623

624

625

626

627

628

629

630

631

632

633

634

635

636

637

638

639

640

641

642

643

644

645

646

647

648

649

650

651

652

653

654

655

656

and Ecology 366:99-103. DOI: 10.1016/j.jembe.2008.07.013.

Fernandes AD., Reid JN., Macklaim JM., McMurrough TA., Edgell DR., Gloor GB. 2014. Unifying the analysis of high-throughput sequencing datasets: characterizing RNA-seq, 16S rRNA gene sequencing and selective growth experiments by compositional data analysis. Microbiome 2:15. DOI: 10.1186/2049-2618-2-15.

Fox J., Friendly M., Weisberg S. 2013. Hypothesis Tests for Multivariate Linear Models Using the car Package. The R Journal 5:39-52.

Furnas M., Mitchell A., Skuza M., Brodie J. 2005. In the other 90\%: phytoplankton responses to enhanced nutrient availability in the Great Barrier Reef Lagoon. Marine Pollution Bulletin 51:253-265. DOI: 10.1016/j.marpolbul.2004.11.010.

Gardner TA., Côté IM., Gill JA., Grant A., Watkinson AR. 2003. Long-term region-wide declines in Caribbean corals. Science 301:958-960. DOI: 10.1126/science.1086050.

Garren M., Raymundo L., Guest J., Harvell CD., Azam F. 2009. Resilience of coral-associated bacterial communities exposed to fish farm effluent. PloS one 4:e7319. DOI: 10.1371/journal.pone.0007319.

Garren M., Smriga S., Azam F. 2008. Gradients of coastal fish farm effluents and their effect on coral reef microbes. Environmental Microbiology 10:2299-2312. DOI: 10.1111/j.14622920.2008.01654.x.

Golbuu Y., Fabricius K., Victor S., Richmond R. 2008. Gradients in coral reef communities exposed to muddy river discharge in Pohnpei, Micronesia. Estuarine, Coastal and Shelf Science 76:14-20. DOI: 10.1016/j.ecss.2007.06.005.

Hallock P., Schlager W. 1986. Nutrient Excess and the Demise of Coral Reefs and Carbonate Platforms. PALAIOS 1:389-398. DOI: 10.2307/3514476.

Hassenrück C., Fink A., Lichtschlag A., Tegetmeyer HE., De Beer D., Ramette A. 2016. Quantification of the effects of ocean acidification on sediment microbial communities in the environment: The importance of ecosystem approaches. FEMS Microbiology Ecology 92:112. DOI: $10.1093 / \mathrm{femsec} / \mathrm{fiw} 027$.

Hill MO. 1973. Diversity and evenness: a unifying notation and its consequences. Ecology 54:427432. DOI: $10.2307 / 1934352$.

Hsieh TC., Ma KH., Chao A. 2016. iNEXT: an R package for rarefaction and extrapolation of species diversity (Hill numbers). Methods in Ecology and Evolution 7:1451-1456. DOI: 10.1111/2041-210X.12613.

Hwang D-W., Lee Y-W., Kim G. 2005. Large submarine groundwater discharge and benthic eutrophication in Bangdu Bay on volcanic Jeju Island, Korea. Limnology and Oceanography 50:1393-1403. DOI: 10.4319/lo.2005.50.5.1393.

Jeffrey ES., Murphy MA. 2017. Package " rfUtilities ." CRAN repository.

Karl DM., Hebel D V., Bjørkman K., Letelier RM. 1998. The role of dissolved organic matter release in the productivity of the oligotrophic North Pacific Ocean. Limnology and Oceanography 43:1270-1286. DOI: 10.4319/lo.1998.43.6.1270.

Kegler HF., Lukman M., Teichberg M., Plass-Johnson J., Hassenrück C., Wild C., Gärdes A. 2017. Bacterial community composition and potential driving factors in different reef habitats of the spermonde archipelago, Indonesia. Frontiers in Microbiology 8. DOI: 10.3389/fmicb.2017.00662.

Kim G. 2003. Large submarine groundwater discharge (SGD) from a volcanic island. Geophysical Research Letters 30:2098. DOI: 10.1029/2003GL018378.

Kiørboe T., Hansen JLS. 1993. Phytoplankton aggregate formation: observations of patterns and 
657

658

659

660

661

662

663

664

665

666

667

668

669

670

671

672

673

674

675

676

677

678

679

680

681

682

683

684

685

686

687

688

689

690

691

692

693

694

695

696

697

698

699

700

701

702 mechanisms of cell sticking and the significance of exopolymeric material. Journal of Plankton Research 15:993-1018. DOI: 10.1093/plankt/15.9.993.

Kirchman DL. 2002. The ecology of Cytophaga-Flavobacteria in aquatic environments. FEMS Microbiology Ecology 39:91-100. DOI: 10.1111/j.1574-6941.2002.tb00910.x.

Klindworth A., Pruesse E., Schweer T., Peplies J., Quast C., Horn M., Glöckner FO. 2013. Evaluation of general 16S ribosomal RNA gene PCR primers for classical and nextgeneration sequencing-based diversity studies. Nucleic Acids Research 41:1-11. DOI: 10.1093/nar/gks808.

Kline DI., Kuntz NM., Breitbart M., Knowlton N., Rohwer F. 2006. Role of elevated organic carbon levels and microbial activity in coral mortality. Marine Ecology Progress Series 314:119-125. DOI: 10.3354/meps314119.

Koop K., Booth D., Broadbent A., Brodie J., Bucher D., Capone D., Coll J., Dennison W., Erdmann M., Harrison P., Hoegh-Guldberg O., Hutchings P., Jones GB., Larkum AWD., O’Neil J., Steven A., Tentori E., Ward S., Williamson J., Yellowlees D. 2001. ENCORE: The Effect of Nutrient Enrichment on Coral Reefs. Synthesis of Results and Conclusions. Marine Pollution Bulletin 42:91-120. DOI: 10.1016/S0025-326X(00)00181-8.

Kuhn M. 2017. Package " caret ." CRAN repository.

Kuntz N., Kline D., Sandin S., Rohwer F. 2005. Pathologies and mortality rates caused by organic carbon and nutrient stressors in three Caribbean coral species. Marine Ecology Progress Series 294:173-180. DOI: 10.3354/meps294173.

Kuznetsova A., Brockhoff PB., Christensen RHB. 2016. lmerTest: Tests in Linear Mixed Effects Models.

Lamb JB., Van De Water JAJM., Bourne DG., Altier C., Hein MY., Fiorenza EA., Abu N., Jompa J., Harvell CD. 2017. Seagrass ecosystems reduce exposure to bacterial pathogens of humans, fishes, and invertebrates. Science 355:731-733. DOI: 10.1126/science.aal1956.

Lapointe B. 2004. The relative importance of nutrient enrichment and herbivory on macroalgal communities near Norman's Pond Cay, Exumas Cays, Bahamas: a "natural" enrichment experiment. Journal of Experimental Marine Biology and Ecology 298:275-301. DOI: 10.1016/S0022-0981(03)00363-0.

Lapointe BE., Barile PJ., Matzie WR. 2004. Anthropogenic nutrient enrichment of seagrass and coral reef communities in the Lower Florida Keys: discrimination of local versus regional nitrogen sources. Journal of Experimental Marine Biology and Ecology 308:23-58. DOI: 10.1016/j.jembe.2004.01.019.

Lauro FM., McDougald D., Thomas T., Williams TJ., Egan S., Rice S., DeMaere MZ., Ting L., Ertan H., Johnson J., Ferriera S., Lapidus A., Anderson I., Kyrpides N., Munk AC., Detter C., Han CS., Brown M V., Robb FT., Kjelleberg S., Cavicchioli R. 2009. The genomic basis of trophic strategy in marine bacteria. Proceedings of the National Academy of Sciences of the United States of America 106:15527-33. DOI: 10.1073/pnas.0903507106.

Laws EA., Brown D., Peace C. 2004. Coastal Water Quality in the Kihei and Lahaina Districts Of the Island of Maui, Hawaiian Islands: Impacts from Physical Habitat and Groundwater Seepage: Implications for Water Quality Standards. International Journal of Environment and Pollution 22:531-546. DOI: 10.1504/IJEP.2004.005908.

Legendre P., Legendre L. 1998. Numerical Ecology, Vol. 2. Amsterdam: Elsevier Science BV.

Liaw a., Wiener M. 2002. Classification and Regression by randomForest. $R$ news 2:18-22. DOI: 10.1177/154405910408300516.

Lyons MM., Lau YT., Carden WE., Ward JE., Roberts SB., Smolowitz R., Vallino J., Allam B. 
703

704

705

706

707

708

709

710

711

712

713

714

715

716

717

718

719

720

721

722

723

724

725

726

727

728

729

730

731

732

733

734

735

736

737

738

739

740

741

742

743

744

745

746

747

748
2007. Characteristics of marine aggregates in shallow-water ecosystems: Implications for disease ecology. EcoHealth 4:406-420. DOI: 10.1007/s10393-007-0134-0.

Lyons MM., Ward JE., Gaff H., Hicks RE., Drake JM., Dobbs FC. 2010. Theory of island biogeography on a microscopic scale: Organic aggregates as islands for aquatic pathogens. Aquatic Microbial Ecology 60:1-13. DOI: 10.3354/ame01417.

Lyons MM., Ward JE., Smolowitz R., Uhlinger KR., Gast RJ. 2005. Lethal marine snow: Pathogen of bivalve mollusc concealed in marine aggregates. Limnology and Oceanography 50:19831988. DOI: $10.4319 / 10.2005 .50 .6 .1983$.

Meyer-Reil L-A., Köster M. 2000. Eutrophication of Marine Waters: Effects on Benthic Microbial Communities. Marine Pollution Bulletin 41:255-263. DOI: 10.1016/S0025-326X(00)001144.

Morris RM., Frazar CD., Carlson CA. 2012. Basin-scale patterns in the abundance of SAR11 subclades, marine Actinobacteria (OM1), members of the Roseobacter clade and OCS116 in the South Atlantic. Environmental Microbiology 14:1133-1144. DOI: $10.1111 / \mathrm{j} .1462-$ 2920.2011.02694.x.

Nasir A., Lukman M., Tuwo A., Hatta M., Tambaru R., Nurfadilah N. 2016. The Use of C/N Ratio in Assessing the Influence of Land-Based Material in Coastal Water of South Sulawesi and Spermonde Archipelago, Indonesia. Frontiers in Marine Science 3:1-8. DOI: 10.3389/fmars.2016.00266.

Nelson CE., Alldredge AL., McCliment EA., Amaral-Zettler LA., Carlson CA. 2011. Depleted dissolved organic carbon and distinct bacterial communities in the water column of a rapidflushing coral reef ecosystem. The ISME journal 5:1374-87. DOI: 10.1038/ismej.2011.12.

Nielsen LP., Risgaard-Petersen N., Fossing H., Christensen PB., Sayama M. 2010. Electric currents couple spatially separated biogeochemical processes in marine sediment. Nature 463:1071-1074. DOI: 10.1038/nature08790.

Oksanen J., Blanchet FG., Friendly M., Kindt R., Legendre P., McGlinn D., Minchin PR., O’Hara RB., Simpson GL., Solymos P., Stevens MHH., Szoecs E., Wagner H. 2016. vegan: Community Ecology Package.

Paerl HW., Dyble J., Moisander PH., Noble RT., Piehler MF., Pinckney JL., Steppe TF., Twomey L., Valdes LM. 2003a. Microbial indicators of aquatic ecosystem change: current applications to eutrophication studies. FEMS microbiology ecology 46:233-46. DOI: 10.1016/S01686496(03)00200-9.

Paerl H., Valdes L., Pinckney J., Piehler M. 2003b. Phytoplankton photopigments as indicators of estuarine and coastal eutrophication. BioScience 53:953-964.

Paradis E., Claude J., Strimmer K. 2004. APE: Analyses of phylogenetics and evolution in R language. Bioinformatics 20:289-290. DOI: 10.1093/bioinformatics/btg412.

Passow U. 2002. Transparent exopolymer particles (TEP) in aquatic environments. Progress in Oceanography 55:287-333. DOI: 10.1016/S0079-6611(02)00138-6.

Passow U., Alldredge AL. 1994. Distribution, size and bacterial colonization of transparent exopolymer particles (TEP) in the ocean. Marine Ecology Progress Series 113:185-198.

Passow U., Alldredge AL. 1995. A dye-binding assay for the spectrophotometric measurement of transparent exopolymer particles (TEP). Limnol. Oceanogr. 40:1326-1335.

Paytan A., Shellenbarger GG., Street JH., Gonneea ME., Davis K., Young MB., Moore WS. 2006. Submarine groundwater discharge: An important source of new inorganic nitrogen to coral reef ecosystems. Limnology and Oceanography 51:343-348. DOI: 10.4319/1o.2006.51.1.0343. 
749

750

751

752

753

754

755

756

757

758

759

760

761

762

763

764

765

766

767

768

769

770

771

772

773

774

775

776

777

778

779

780

781

782

783

784

785

786

787

788

789

790

791

792

793

794

Pet-Soede C., Van Densen WLT., Hiddink JG., Kuyl S., Machiels M a. M. 2001. Can fishermen allocate their fishing effort in space and time on the basis of their catch rates? An example from Spermonde Archipelago, SW Sulawesi, Indonesia. Fisheries Management and Ecology 8:15-36. DOI: 10.1046/j.1365-2400.2001.00215.x.

Pfeffer C., Larsen S., Song J., Dong M., Besenbacher F., Meyer RL., Kjeldsen KU., Schreiber L., Gorby Y a., El-Naggar MY., Leung KM., Schramm A., Risgaard-Petersen N., Nielsen LP. 2012. Filamentous bacteria transport electrons over centimetre distances. Nature:10-13. DOI: 10.1038 /nature 11586 .

Pinhassi J., Sala MM., Havskum H., Peters F., Guadayol Ò., Malits A., Marrasé C. 2004. Changes in bacterioplankton composition under different phytoplankton regimens. Applied and Environmental Microbiology 70:6753-6766. DOI: 10.1128/AEM.70.11.6753-6766.2004.

Plass-Johnson JG., Ferse SCA., Jompa J., Wild C., Teichberg M. 2015. Fish herbivory as key ecological function in a heavily degraded coral reef system. Limnology and Oceanography 60:1382-1391. DOI: 10.1002/lno.10105.

Polónia ARM., Cleary DFR., de Voogd NJ., Renema W., Hoeksema BW., Martins A., Gomes NCM. 2015. Habitat and water quality variables as predictors of community composition in an Indonesian coral reef: A multi-taxon study in the Spermonde Archipelago. Science of the Total Environment 537:139-151. DOI: 10.1016/j.scitotenv.2015.07.102.

Quast C., Pruesse E., Yilmaz P., Gerken J., Schweer T., Yarza P., Peplies J., Glöckner FO. 2013. The SILVA ribosomal RNA gene database project: Improved data processing and web-based tools. Nucleic Acids Research 41:590-596. DOI: 10.1093/nar/gks1219.

R Core Team. 2016. R: A language and environment for statistical computing.

Rädecker N., Pogoreutz C., Voolstra CR., Wiedenmann J., Wild C. 2015. Nitrogen cycling in corals: the key to understanding holobiont functioning? Trends in Microbiology. DOI: 10.1016/j.tim.2015.03.008.

Reguera G. 2012. Microbiology: Bacterial power cords. Nature:8-9. DOI: 10.1038/nature11638.

Renema W., Troelstra SR. 2001. Larger foraminifera distribution on a mesotrophic carbonate shelf in SW Sulawesi (Indonesia). Palaeogeography, Palaeoclimatology, Palaeoecology 175:125146. DOI: 10.1016/S0031-0182(01)00389-3.

Reopanichkul P., Carter RW., Worachananant S., Crossland CJ. 2010. Wastewater discharge degrades coastal waters and reef communities in southern Thailand. Marine environmental research 69:287-96. DOI: 10.1016/j.marenvres.2009.11.011.

Rohwer F., Seguritan V., Azam F., Knowlton N. 2002. Diversity and distribution of coralassociated bacteria. Marine Ecology Progress Series 243:1-10. DOI: 10.3354/meps243001.

Rosenberg E., Koren O., Reshef L., Efrony R., Zilber-Rosenberg I. 2007. The role of microorganisms in coral health, disease and evolution. Nature reviews. Microbiology 5:35562. DOI: $10.1038 /$ nrmicro1635.

RStudio Team. 2017. RStudio: Integrated Development for R.

Sato Y., Ling EYS., Turaev D., Laffy P., Weynberg KD., Rattei T., Willis BL., Bourne DG. 2017. Unraveling the microbial processes of black band disease in corals through integrated genomics. Scientific Reports 7:1-14. DOI: 10.1038/srep40455.

Sawall Y., Richter C., Ramette A. 2012. Effects of eutrophication, seasonality and macrofouling on the diversity of bacterial biofilms in equatorial coral reefs. PloS ONE 7:e39951. DOI: 10.1371/journal.pone.0039951.

Schwerdtner Máñez K., Husain S., Ferse SCA., Máñez Costa M. 2012. Water scarcity in the Spermonde Archipelago, Sulawesi, Indonesia: Past, present and future. Environmental

PeerJ reviewing PDF | (2017:11:21924:1:1:NEW 19 Feb 2018) 
795

796

797

798

799

800

801

802

803

804

805

806

807

808

809

810

811

812

813

814

815

816

817

818

819

820

821

822

823

824

825

826

827

828

829

830

831

832

833

834

835

836

837

838

839

840

Science and Policy 23:74-84. DOI: 10.1016/j.envsci.2012.07.004.

Simpson GL. 2016. permute: Functions for Generating Restricted Permutations of Data.

Stocker R. 2012. Marine Microbes See a Sea of Gradients. Science 338:628-633. DOI: 10.1126/science. 1208929.

Street JH., Knee KL., Grossman EE., Paytan A. 2008. Submarine groundwater discharge and nutrient addition to the coastal zone and coral reefs of leeward Hawai'i. Marine Chemistry 109:355-376. DOI: 10.1016/j.marchem.2007.08.009.

Szmant a. M., Forrester a. 1996. Water column and sediment nitrogen and phosphorus distribution patterns in the Florida Keys, USA. Coral Reefs 15:21-41. DOI: 10.1007/BF01626075.

Tout J., Jeffries TC., Webster NS., Stocker R., Ralph PJ., Seymour JR. 2014. Variability in Microbial Community Composition and Function Between Different Niches Within a Coral Reef. Microbial ecology. DOI: 10.1007/s00248-013-0362-5.

Udy J., Gall M., Longstaff B., Moore K., Roelfsema C., Spooner DR., Albert S. 2005. Water quality monitoring: a combined approach to investigate gradients of change in the Great Barrier Reef, Australia. Marine pollution bulletin 51:224-38. DOI: 10.1016/j.marpolbul.2004.10.048.

Umezawa YU., Miyajima TM., Kayanne HK., Koike IK. 2002. Significance of groundwater nitrogen discharge into coral reefs at Ishigaki Island, southwest of Japan. Coral Reefs 21:346356. DOI: $10.1007 / \mathrm{s} 00338-002-0254-5$.

Uthicke S., McGuire K. 2007. Bacterial communities in Great Barrier Reef calcareous sediments: Contrasting 16S rDNA libraries from nearshore and outer shelf reefs. Estuarine, Coastal and Shelf Science 72:188-200. DOI: 10.1016/j.ecss.2006.10.017.

Verdugo P., Alldredge AL., Azam F., Kirchman DL., Passow U., Santschi PH. 2004. The oceanic gel phase: a bridge in the DOM-POM continuum. Marine Chemistry 92:67-85. DOI: 10.1016/j.marchem.2004.06.017.

de Voogd NJ., Cleary DFR., Polonia a. RM., Gomes NCM. 2015. Bacterial community composition and predicted functional ecology of sponges, sediment and seawater from the thousand-islands reef complex, West-Java, Indonesia. FEMS Microbiology Ecology 91:1-12. DOI: $10.1093 /$ femsec/fiv019.

Warnes AGR., Bolker B., Bonebakker L., Huber W., Liaw A., Lumley T., Magnusson A., Moeller S., Schwartz M. 2016. Package " gplots .” CRAN repository.

Weinbauer MG., Kerros ME., Motegi C., Wilhartitz IC., Rassoulzadegan F., Torreton JP., Mari X. 2010. Bacterial community composition and potential controlling mechanisms along a trophic gradient in a barrier reef system. Aquatic Microbial Ecology 60:15-28. DOI: 10.3354/ame01411.

Welch EB., Isaac GW. 1967. Chlorophyll variation with tide and with plankton productivity in an estuary. J Water Pollut Control Fed 39:360-366.

White I., Falkland T. 2010. Management of freshwater lenses on small Pacific islands. Hydrogeology Journal 18:227-246. DOI: 10.1007/s10040-009-0525-0.

Wickham H. 2007. Reshaping Data with the reshape Package. Journal of Statistical Software 21:1-25. DOI: 10.18637/jss.v021.i12.

Wickham H. 2011. The Split-Apply-Combine Strategy for Data Analysis. Journal of Statistical Software 40. DOI: 10.18637/jss.v040.i01.

Wild C., Rasheed M., Werner U., Franke U., Johnstone R., Huettel M. 2004. Degradation and mineralization of coral mucus in reef environments. Marine Ecology Progress Series 267:159-171. 
841 Williams TJ., Wilkins D., Long E., Evans F., Demaere MZ., Raftery MJ., Cavicchioli R. 2013. 842 The role of planktonic Flavobacteria in processing algal organic matter in coastal East Antarctica revealed using metagenomics and metaproteomics. Environmental Microbiology 15:1302-1317. DOI: 10.1111/1462-2920.12017.

Witt V., Wild C., Uthicke S. 2012. Terrestrial runoff controls the bacterial community composition of biofilms along a water quality gradient in the Great Barrier Reef. Applied and environmental microbiology 78:7786-91. DOI: 10.1128/AEM.01623-12.

Wolanski E., Martinez J a., Richmond RH. 2009. Quantifying the impact of watershed urbanization on a coral reef: Maunalua Bay, Hawaii. Estuarine, Coastal and Shelf Science 84:259-268. DOI: 10.1016/j.ecss.2009.06.029.

Yang C., Li Y., Zhou B., Al. E. 2015. Illumina sequencing-based analysis of free-living bacterial community dynamics during an Akashiwo sanguine bloom in Xiamen sea, China. Scientific Reports. DOI: doi:10.1038/srep08476.

Zhang R., Lau SCK., Ki J-S., Thiyagarajan V., Qian P-Y. 2009. Response of bacterioplankton community structures to hydrological conditions and anthropogenic pollution in contrasting subtropical environments. FEMS microbiology ecology 69:449-460. DOI: 10.1111/j.15746941.2009.00726.x.

Zhang R., Liu B., Lau SCK., Ki J-S., Qian P-Y. 2007. Particle-attached and free-living bacterial communities in a contrasting marine environment: Victoria Harbor, Hong Kong. FEMS

861 Microbiology Ecology 61:496-508. DOI: 10.1111/j.1574-6941.2007.00353.x.

862

863 
Figure $\mathbf{1}$ (on next page)

Map of the sampling area.

A: Spermonde archipelago, South Sulawesi, Indonesia. B: Close-up of the two sampled islands Pulau Barrang Lompo (inhabited) and Pulau Kodingareng Keke (uninhabited) including the position of the sampling sites along the south and north transects across the back-reef area. 


\section{Figure 2 (on next page)}

Water quality parameters at the inhabited and uninhabited island.

A: Nitrite/nitrate $\left(\mathrm{NO}_{\mathrm{x}}{ }^{-}\right)$. B: Phosphate $\left(\mathrm{PO}_{4}{ }^{3-}\right)$. C: Silicate (Si). D: Chlorophyll a (Chl a). E:

Dissolved organic carbon (DOC). F: Transparent exopolymer particles (TEP). Error bars depict standard deviation. 


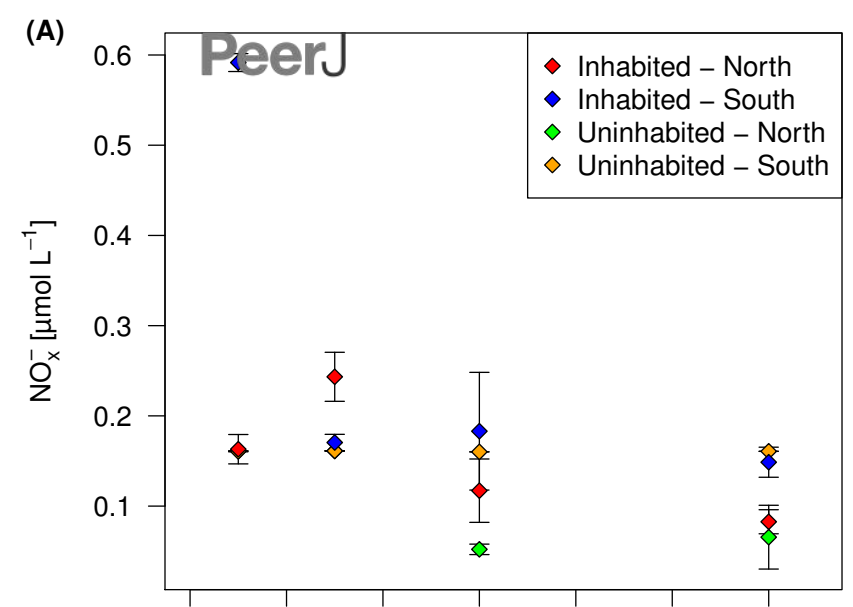

(B)

(C)

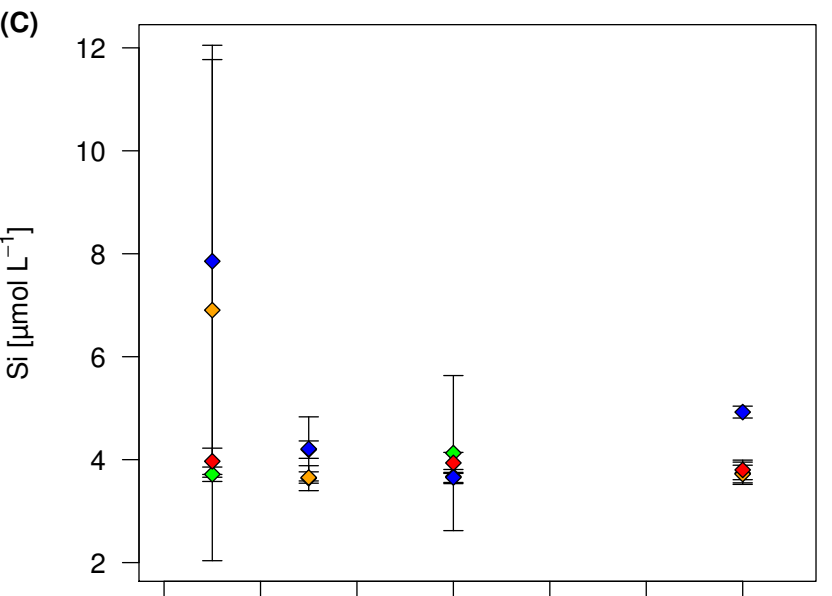

(E)
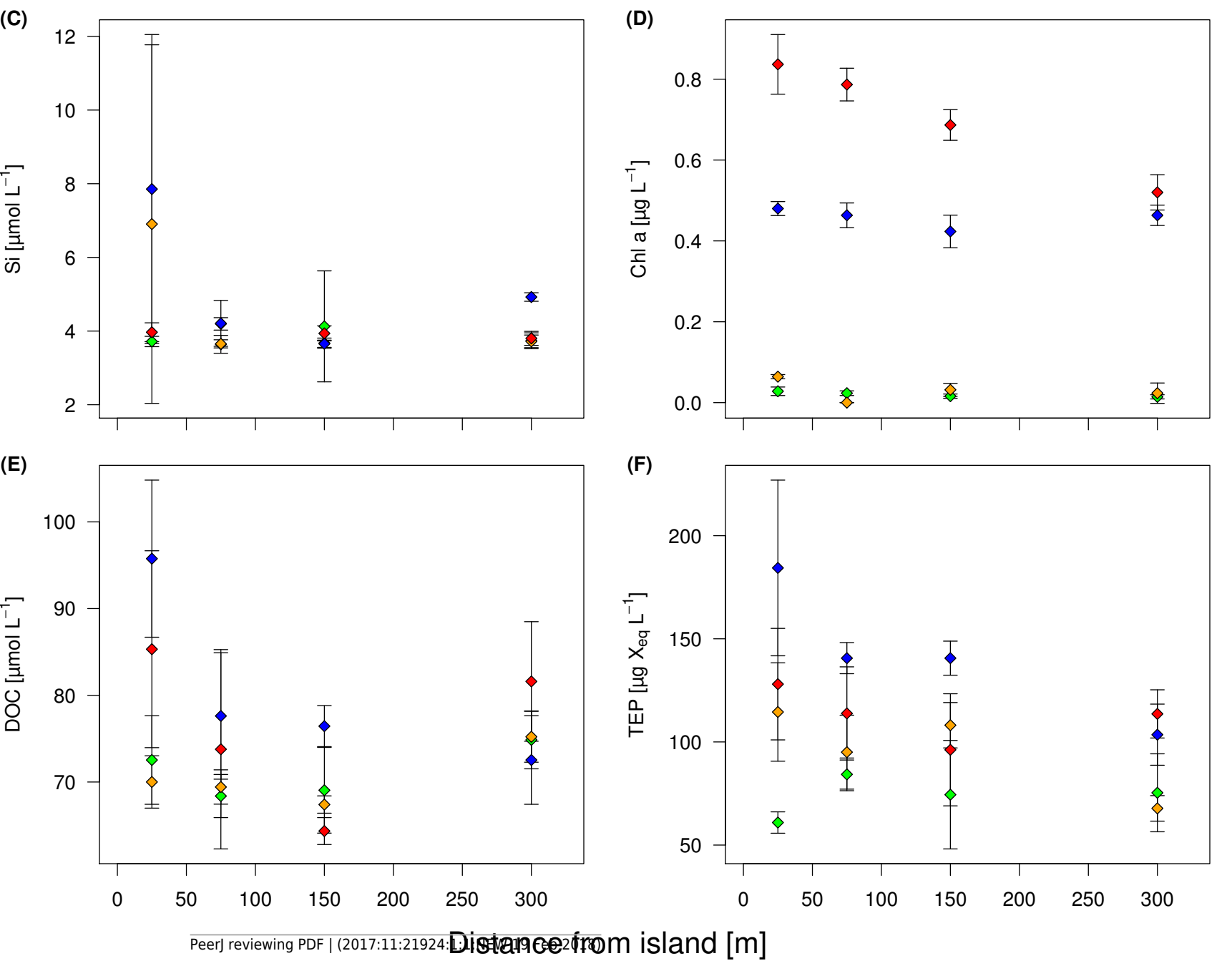
Figure 3 (on next page)

PCA ordination of the measured water quality parameters at the inhabited and uninhabited island.

PC1 and PC2 explained $52.42 \%$ and $18.43 \%$ of the total variation, respectively. $\mathrm{NO}_{x}$ : nitrite/nitrate, $\mathrm{PO}_{4}^{3 \cdot}$ : phosphate, Si: silicate, $\mathrm{Chl}$ a: Chlorophyll a, DOC: dissolved organic carbon, TEP: transparent exopolymer particles. 


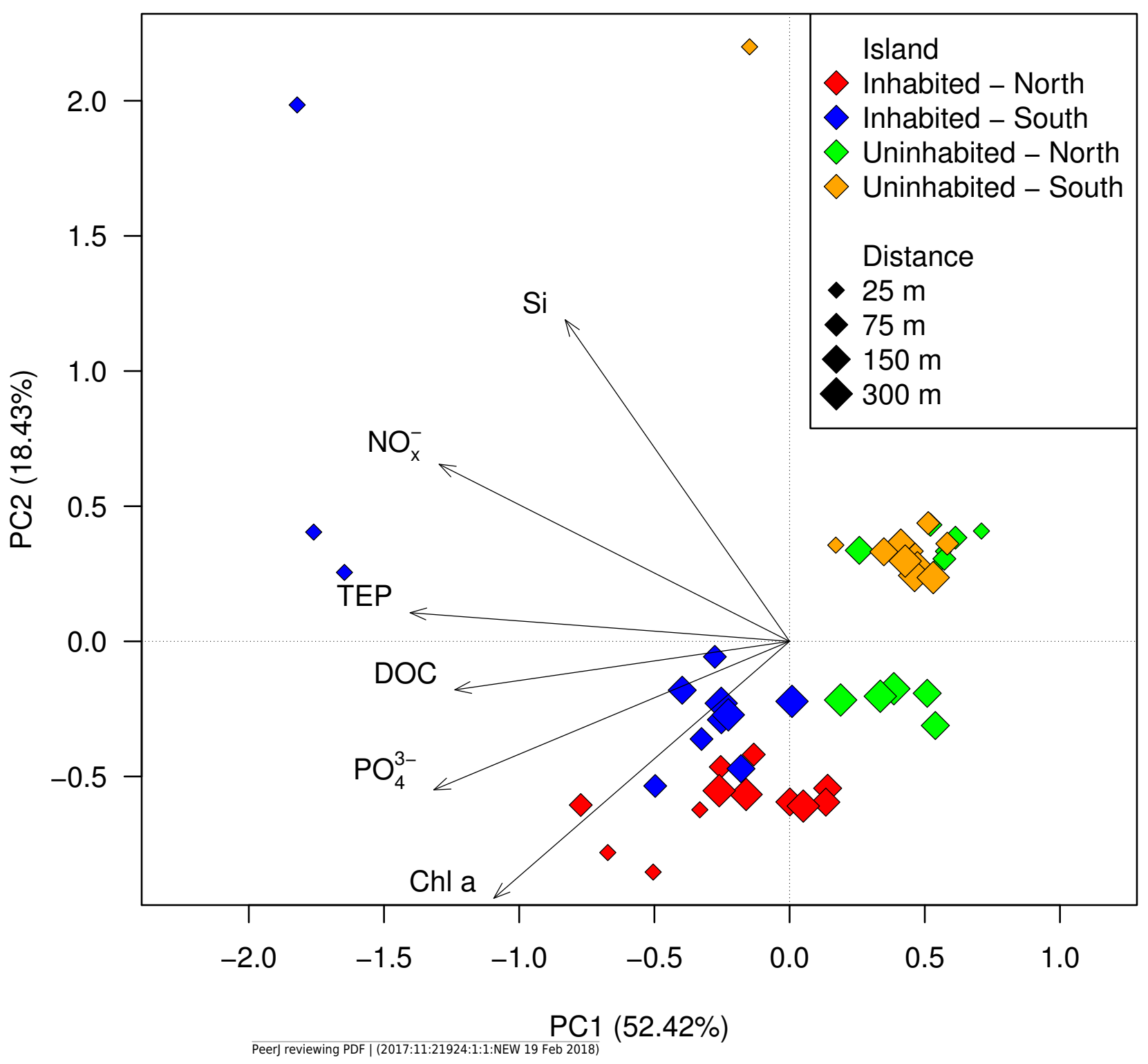


Figure 4 (on next page)

Relative sequence abundance of bacterial classes in each sampled habitat at the inhabited island and uninhabited island.

FL: Free-living bacterial communities of the water column ( $>0.2 \mu \mathrm{m})$, PA: Particle-attached bacterial communities of the water column ( $>3 \mu \mathrm{m})$, SED: Bacterial communities in reef sediments. 


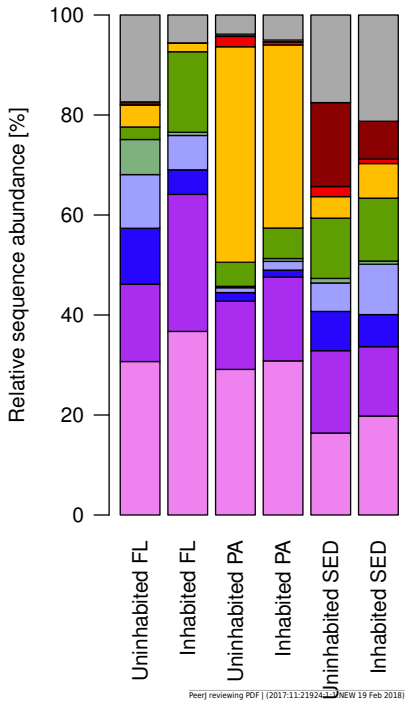

$\square$ other

- Planctomycetacia

$\square$ Phycisphaerae

$\square$ Cyanobacteria

$\square$ Flavobacteriia

$\square$ Clostridia

$\square$ Deltaproteobacteria

- Acidimicrobiia

$\square$ Alphaproteobacteria

$\square$ Gammaproteobacteria 
Figure $\mathbf{5}$ (on next page)

NMDS plot of the bacterial communities of each sampled habitat at the inhabited island and uninhabited island.

A: Free-living bacterial communities of the water column ( $>0.2 \mu \mathrm{m} ; \mathrm{FL}), 2 \mathrm{D}$ stress: 0.11 . B: Particle-attached bacterial communities of the water column (> $3 \mu \mathrm{m}$; PA), 2D-stress; 0.07. C: Bacterial communities in reef sediments (SED), 2D-stress: 0.10. Arrows indicate envfit correlations of the water quality parameters with bacterial community composition. $\mathrm{NO}_{x}$ : nitrite/nitrate, $\mathrm{PO}_{4}{ }^{3-}$ :phosphate, Si: silicate, $\mathrm{Chl}$ a: Chlorophyll a, DOC: dissolved organic carbon, TEP: transparent exopolymer particles. 


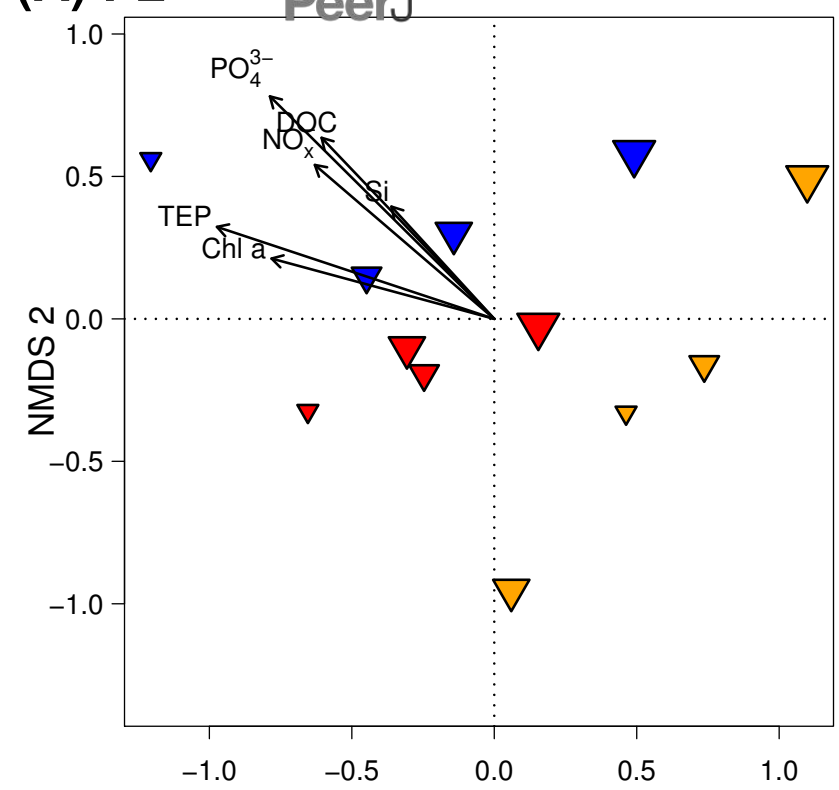

C) SED

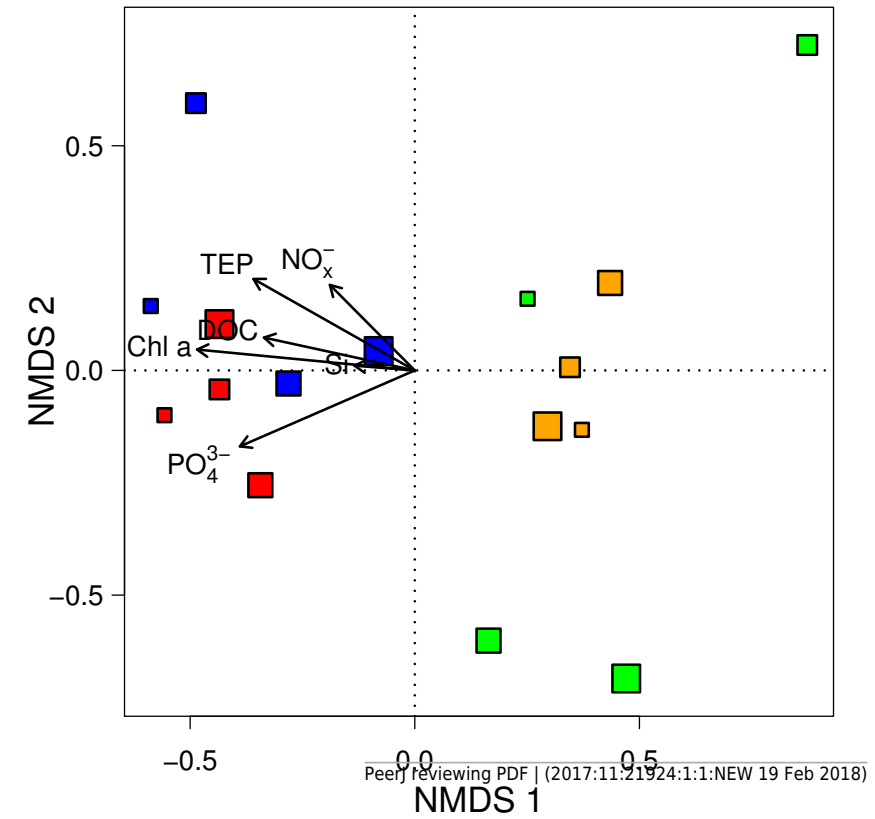

(B) PA

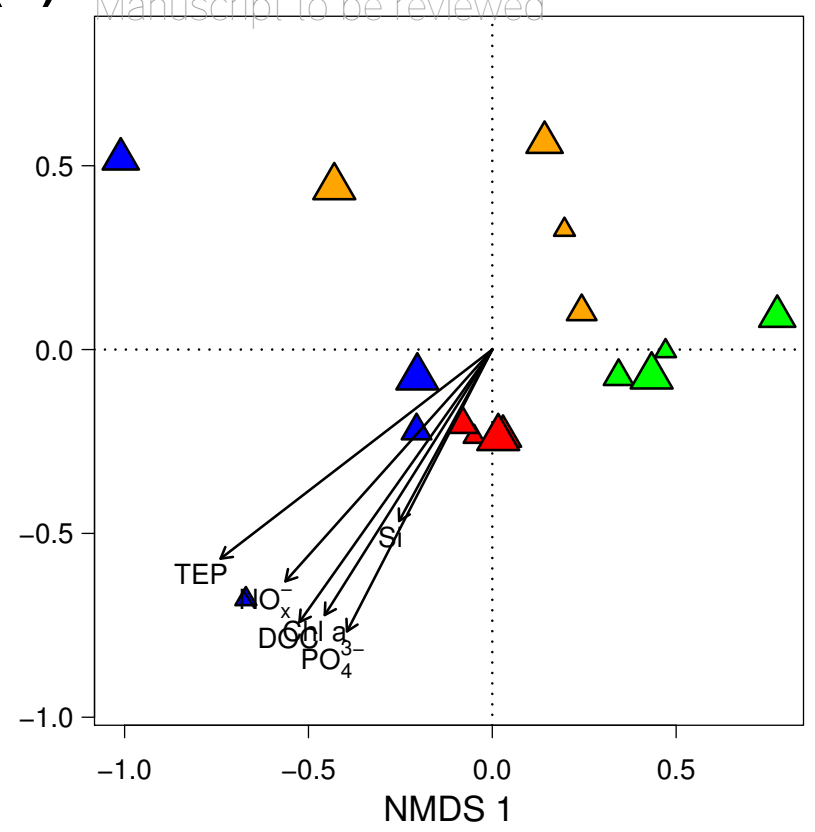

\section{Habitat \\ $\square$ SED}

$\nabla$ FL

$\triangle \mathrm{PA}$

Island

- Inhabited - North

- Inhabited - South

$\checkmark$ Uninhabited - North

$\checkmark$ Uninhabited - South

Distance

- $25 \mathrm{~m}$

- $75 \mathrm{~m}$

- $150 \mathrm{~m}$

$300 \mathrm{~m}$ 


\section{Table $\mathbf{1}$ (on next page)}

Differences in water quality between islands and with increasing distance from the island, as well as the interaction of these two factors, assess by GLMMs.

P-values defined as significant at a threshold of 0.05 are highlighted in bold. ${ }^{a} \mathrm{NO}_{\mathrm{x}}:$ : nitrite/nitrate, $\mathrm{PO}_{4}{ }^{3-}$ : phosphate, Si: silicate, Chl a: Chlorophyll a, DOC: dissolved organic carbon, TEP: transparent exopolymer particles. 
1 Table 1: Differences in water quality between islands and with increasing distance from the island, as well as the 2 interaction of these two factors, assess by GLMMs. P-values defined as significant at a threshold of 0.05 are 3 highlighted in bold.

\begin{tabular}{lrrrrrr}
\hline Parameter $^{\mathrm{a}}$ & \multicolumn{2}{c}{ Island } & \multicolumn{2}{c}{ Distance } & \multicolumn{2}{c}{ Interaction } \\
\cline { 2 - 7 } & \multicolumn{1}{c}{$\mathrm{F}$} & $\mathrm{p}$-value & \multicolumn{1}{c}{$\mathrm{F}$} & $\mathrm{p}$-value & \multicolumn{1}{c}{$\mathrm{p}$} & $\mathrm{p}$-value \\
\hline $\mathrm{NO}_{\mathrm{x}}{ }^{-}$ & 10.178 & $\mathbf{0 . 0 0 3}$ & 28.985 & $<\mathbf{0 . 0 0 1}$ & 2.099 & 0.155 \\
$\mathrm{PO}_{4}{ }^{3-}$ & 66.904 & $<\mathbf{0 . 0 0 1}$ & 4.859 & $\mathbf{0 . 0 3 3}$ & 14.649 & $<\mathbf{0 . 0 0 1}$ \\
$\mathrm{Si}$ & 0.659 & 0.421 & 2.410 & 0.128 & 0.001 & 0.977 \\
$\mathrm{Chl} \mathrm{a}$ & 322.943 & $<\mathbf{0 . 0 0 1}$ & 7.753 & $\mathbf{0 . 0 0 8}$ & 4.133 & $\mathbf{0 . 0 4 8}$ \\
$\mathrm{DOC}$ & 14.239 & $<\mathbf{0 . 0 0 1}$ & 0.412 & 0.525 & 5.272 & $\mathbf{0 . 0 2 6}$ \\
$\mathrm{TEP}$ & 19.621 & $<\mathbf{0 . 0 0 1}$ & 8.406 & $\mathbf{0 . 0 0 6}$ & 0.421 & 0.520 \\
\hline
\end{tabular}

$4{ }^{a} \mathrm{NO}_{\mathrm{x}}{ }^{-}:$nitrite/nitrate, $\mathrm{PO}_{4}{ }^{3-}:$ phosphate, Si: silicate, Chl a: Chlorophyll a, DOC: dissolved organic carbon, TEP:

5 transparent exopolymer particles 


\section{Table 2 (on next page)}

Contribution of environmental factors (inhabitation status and water quality parameters) to explaining variation in bacterial community composition in each of the sampled habitats based on redundancy analysis (RDA).

P-values defined as significant at a threshold of 0.05 are highlighted in bold. Akaike Information Criterion (AIC) and adjusted $\mathrm{R}^{2}$ are provided as goodness-of-fit metrics. Df: degrees of freedom (numerator, denominator), $\mathrm{PO}_{4}{ }^{3-}$ : phosphate, Chla:Chlorophyll a, TEP: transparent exopolymer particles. 
1 Table 2: Contribution of environmental factors (inhabitation status and water quality parameters) to explaining 2 variation in bacterial community composition in each of the sampled habitats based on redundancy analysis (RDA).

\begin{tabular}{|c|c|c|c|c|c|c|}
\hline Habitat & Explanatory variable & AIC & Adjusted $\mathrm{R}^{2}$ & $\mathrm{~F}$ & $\mathrm{df}$ & p-value \\
\hline \multicolumn{7}{|c|}{ Free-living } \\
\hline & Inhabitation status & 98.94 & $10.1 \%$ & 2.230 & 1,10 & 0.011 \\
\hline & $\mathrm{Chl} \mathrm{a}+\mathrm{PO}_{4}^{3-}$ & 96.86 & $28.9 \%$ & 3.233 & 2,9 & 0.001 \\
\hline & Chl a (pure) & & $17.1 \%$ & 3.407 & 1,9 & 0.001 \\
\hline & $\mathrm{PO}_{4}{ }^{3-}$ (pure) & & $16.8 \%$ & 3.364 & 1,9 & 0.001 \\
\hline \multicolumn{7}{|c|}{ Particle-attached } \\
\hline & Inhabitation status & 136.61 & $9.7 \%$ & 2.619 & 1,14 & 0.001 \\
\hline & Chl a + TEP & 136.59 & $14.3 \%$ & 2.254 & 2,13 & 0.001 \\
\hline & Chl a (pure) & & $6.0 \%$ & 1.980 & 1,13 & 0.003 \\
\hline & TEP (pure) & & $6.7 \%$ & 2.099 & 1,13 & 0.013 \\
\hline \multicolumn{7}{|l|}{ Sediment } \\
\hline & Inhabitation status & 140.86 & $17.7 \%$ & 4.221 & 1,14 & 0.001 \\
\hline & Chl a & 141.07 & $16.6 \%$ & 3.979 & 1,14 & 0.001 \\
\hline
\end{tabular}

3 Akaike Information Criterion (AIC) and adjusted $\mathrm{R}^{2}$ are provided as goodness-of-fit metrics. Df: degrees of freedom 4 (numerator, denominator), $\mathrm{PO}_{4}{ }^{3-}$ : phosphate, $\mathrm{Chl}$ a: Chlorophyll a, TEP: transparent exopolymer particles. 